\title{
The Challenge of Bioenergies: An Overview
}

\author{
Nicolas Carels \\ Fundação Oswaldo Cruz (FIOCRUZ), Instituto Oswaldo Cruz (IOC), Laboratório de \\ Genômica Funcional e Bioinformática, Rio de Janeiro \\ Brazil
}

\section{Introduction}

The rapid rise in the price of crude oil, the decrease in oil reserves, security concerns and greater recognition of the environmental impacts of fossil fuels have generated considerable interest in biofuels as an alternative energy source. The revolution in transportation that occurred at the beginning of the last century created dependence of Western economies on the combustion of hydrocarbon fuels. The invention of the electric light bulb by T.A. Edison led to the installation of the first energy distribution plant in 1883 (in Roselle, New Jersey) and subsequently the electric grid came to the world. Because of the high rate (typically $>90 \%$ ) and ease of alternative to constant voltage conversion or vice versa, as well as mechanical conversion of electricity, the electric grid became the nervous system of our civilization.

During the $20^{\text {th }}$ century, humanity created a foundation in which electric applications are used in all segments of society. This revolution is now creating a system of pervasive computing and is preparing society for the era of nanotechnologies and robotics. However, the electric grid is dangerously dependent on the availability of carbon-based resources such as coal and natural gas (Song, 2006). Human civilization is now challenged with finding renewable and environmentally friendly energy sources for feeding both our electric grid and our economic growth. For the next two decades, fossil fuels will continue to be the most cost-effective energy resource. However, despite their higher costs, alternative energies have begun to be seriously investigated. It is the purpose of the present work to provide an overview of this issue.

Existing fossil fuels are believed to have originated over the course of millions (M) of years (yrs) from biochemical and geochemical transformations of organic substances that were present on the earth's surface. The geological storage of carbon in the form of fossil fuels can be viewed as one alternative route to the reduction/oxidation cycle of carbon that is occurring at the earth's surface. Numerous studies have shown that coal is formed from biochemical degradation and geochemical maturation of higher-plant materials that were originally generated via photosynthesis. Crude oil also shows fingerprint molecules such as phytane that testify to its plant origin (Johnston et al., 2007).

Crude oil contains various hydrocarbons that range from light gases (e.g., C1-C5) to heavy residues (Fialkov et al., 2008). These hydrocarbons are separated via distillation into three main products, namely naphtha, middle distillate and a residual fraction. Naphtha (boiling range $90-190^{\circ} \mathrm{C}$ ) is mainly used for motor gasoline (C3-C12) and comprises approximately $20 \%$ of the total crude oil. The middle distillate can be separated into two categories 
consisting of kerosene-range products (light-end) and diesel-range products (heavy-end). The light-end middle distillates $\left(25-30 \%\right.$ of total crude oil, boiling range $150-260^{\circ} \mathrm{C}$ ) are used for the manufacture of solvents, kerosene (C8-C16), commercial and military jet fuels (C3C10) and light diesel fuel (diesel fuel No. 1, C8-C22). The heavy-end middle distillates (25$30 \%$ of total crude oil, boiling range $190-400^{\circ} \mathrm{C}$ ) are processed to produce diesel fuel No. 2 (C10-C25) and heating oils (15-20\%) (Kaplan et al., 1997). Lubricating oil (>C18) accounts for approximately $5-7 \%$ of the total crude. In addition to the alkane fraction, there is also a fraction of polycyclic aromatic hydrocarbons (PAH) whose relative importance in the composition of distillates increases from kerosene to heating oil. Beside the gas with green house effects (GHG) and their consequences on climate changes, it is the PAH that cause the most important environmental concerns because of oil spills. Actually, PAHs are rather resistant to microbial degradation (bioremediation) under anaerobic conditions, with the consequence that their removal from impacted environments is very slow. PAHs are also a source of concern regarding human health because they may stick to DNA, resulting in deleterious mutations and ultimately cancer.

World oil consumption is approximately $79 \mathrm{M}$ barrels (bl) per day (a barrel is $159 \mathrm{l}$ ). The transport sector represents $50 \%$ of oil consumption (or $20 \%$ of energy consumption) and has an annual average growth rate of $>2 \%$ per year. Energy demand worldwide is expected to rise by approximately 50\%-60\% over the next 20 years, reaching $112 \mathrm{M} \mathrm{bl}$ /day (Song, 2006). Most of the "cheap oil" that was (relatively) easily removed from the ground (and sold for US\$ 20-30/bl) is already gone, and fossil fuel prices have risen over the past decades. The price of crude oil increased from US $\$ 18 /$ bl in 1990 to US\$ >100/bl in 2008 (Tan et al., 2008).

Fuel prices will probably continue to increase in the future because of the following factors: (i) fossil fuel resources are limited; (ii) there is a lack of balance between supply and demand; (iii) the demand for fossil fuel is rising rapidly; and (iv) geopolitical instability and international conflicts are increasing (Rout et al., 2008).

With fossil fuel prices at US\$ 45/bl, renewable energy from a range of biofuels is becoming economically competitive. Biodiesel fuel usually costs over US\$ 0.5/1 (as compared with US\$ 0.35/1 for fossil diesel fuel - see in Zhang et al., 2003) such that the increase in the use of biodiesel has been particularly rapid over the two last decades. It has grown from essentially zero in 1995 to more than 20 billion (G) liters (l) in 2009 (in the US as well as in Brazil). Brazil and the United States (US) have the largest biofuel programs in the world, with the European Union (EU) ranking in the third position.

Biofuels can potentially mitigate greenhouse gases, can provide means of energy independence and may even provide new employment opportunities. Because they are compatible with existing technologies, they will also alleviate natural resistance to change and may act as a medium to allow a "smooth" transition to alternative technologies (Shinnar \& Citro, 2006) and regulations. Many countries are now utilizing biofuel products resulting from agriculture and forestry. The most commonly cited advantages of biofuels are as follows: (i) they are available from common biomass sources; (ii) they are integrated into the combustion cycle of carbon dioxide $\left(\mathrm{CO}_{2}\right)$; (iii) they are compatible with environmental constraints; and (iv) they contribute to environmental sustainability. For example, biodiesel fuel prepared from vegetable oils or animal fats is compatible with common diesel engines and is therefore a potential alternative to fossil-based diesel fuel. Sulfate emissions resulting from biodiesel combustion are close to zero and the net contribution of $\mathrm{CO}_{2}$ from biofuels when considering their entire life cycle (i.e., cultivation, oil production and conversion to biodiesel) can be low. The rate of pollutant emission over the life cycle of biofuels is 
comparable with that of fossil diesel fuel; however, because it is renewable, biofuel combustion does not result in $\mathrm{CO}_{2}$ accumulation in the atmosphere (Agarwal, 2007). Actually, plants use solar energy to turn atmospheric $\mathrm{CO}_{2}$ and water into organic carbon and hydrogen, thereby storing energy. The organic molecules are then broken down as the plant decays and the carbon is returned to the atmosphere as $\mathrm{CO}_{2}$. When growing a crop for fuel, part of the biomass produced by the plant is used directly to produce energy and the $\mathrm{CO}_{2}$ that was originally metabolized by the plant is returned to the atmosphere during the combustion process. This $\mathrm{CO}_{2}$ is therefore "renewable" because it is simply a portion of the total $\mathrm{CO}_{2}$ that is involved in the natural cycle. However, to produce a biofuel, a certain amount of energy is required. This sophisticated process of production needs a significant energy amount for growing, harvesting and processing the necessary biomass.

The concept of "well-to-wheel" (WTW) is used to characterize the energy consumption that is required to complete the entire process of production and transport of a fuel (Gnansounou et al., 2009). The WTW analysis is often divided into the following five stages:

(i) feedstock production, (ii) feedstock transport, (iii) fuel production, (iv) fuel distribution and (v) vehicle use. These stages can be divided even further into "well-to-tank" (WTT) and "tank-to-wheel" (TTW) processes. Fig. 3 in Agarwal (2007) shows that the rates of pollution with the corresponding increase in energy consumption of crude oil, natural gas, biomass, wind power are 1.3, 1.8, 7.1 and 45 times lower, respectively, than that of coal. Nevertheless, biofuels (such as ethanol and biodiesel) fall on a line with a slope equal to crude oil. However, the intercept is lower, which demonstrates that the benefit of biofuels over fossil diesel fuel is due to the recycling of the former through photosynthesis. More advanced technologies (e.g., synthetic fuels based on biomass gasification or wind electricity) use virtually only renewable energy for the conversion processes and result in very low GHG emissions.

\subsection{The $\mathrm{CO}_{2}$ balance}

Carbon cycling does not occur with fossil fuel use because the released $\mathrm{CO}_{2}$ does not return to fossil resources. The amount of $\mathrm{CO}_{2}$ that has accumulated in the atmosphere is very large and has been calculated to be $\sim 780$ billion (G) tons (t) as of 2002 (Song, 2006). $\mathrm{CO}_{2}$ concentrations are measured by infrared absorption spectroscopy and, because of heterogeneity in the data, estimates may vary from the simple to the double (400 to $780 \mathrm{Gt}$ ). However, all measurements agree with a pattern of monotonic increase in $\mathrm{CO}_{2}$. The concentration is now approximately 390 part per million (ppm), as compared to $310 \mathrm{ppm}$ in 1955 (Song, 2006). Over the same period, the atmospheric temperature has increased by roughly $0.6-0.74{ }^{\circ} \mathrm{C}$ and has resulted in numerous effects on the environment, climate (Odling-Smee, 2007; Rout et al., 2008; Tomkiewicz, 2006), ecosystems (Yue et al., 2010) and (consequently) human populations (Simões et al., 2010). For example, growing seasons are becoming longer with the consequence that the amount of carbon accumulating in terrestrial biomass increased by a factor of 7 between the 1980s and the 1990s. In addition to this terrestrial carbon sink (which plays an important role in slowing the rate of $\mathrm{CO}_{2}$ increase), one must consider the oceanic carbon sink, which sequesters twice as much anthropogenic carbon as does the terrestrial sink (Ridgwell \& Zeebe, 2005). Together, these sinks sequester approximately half of the $\sim 24 \mathrm{Gt}$ of anthropogenic carbon emitted each year. Although values of $\mathrm{CO}_{2}$ emissions should be considered carefully because of the heterogeneity among estimates, one may conclude that phototropic carbon sinks are keys for the mitigation of 
atmospheric $\mathrm{CO}_{2}$ concentrations and, consequently, of global temperatures that will increase during the $21^{\text {st }}$ century (Reay, 2007).

However, there is a limit to $\mathrm{CO}_{2}$ mitigation by phototropic carbon sinks. With the rise in $\mathrm{CO}_{2}$ concentrations in the atmosphere, falling oceanic $\mathrm{pH}$ levels will result in changes in ocean chemistry. This should decrease the efficiency of carbon recycling and, together with the decrease in precipitation, could induce a switch from oceans as a sink to a source of $\mathrm{CO}_{2}$ by 2050. In fact, warmer soils will release more carbon and forests suffering increased drought will eventually decline. In addition, $40 \mathrm{Gt}$ of $\mathrm{CO}_{2}$ that is sequestered in $50 \mathrm{Gt}$ of terrestrial biomass could be released because of changes in land use. Deforestation is the single biggest threat to the terrestrial carbon sink because woody biomass is the most efficient biological system for carbon sequestration (Miles \& Kapos, 2008).

The world's forests cover $\sim 4$ billion (G) hectares (ha) or $30 \%$ of the earth's land surface. In $2005,3.5 \mathrm{Gm}^{3}$ of wood were removed from $434 \mathrm{Gm}^{3}$ of forests; $\sim 60 \%$ of this amount was consumed for industrial purposes and the remainder was used for fuel. Terrestrial forests are either primary $(36 \%)$ or modified $(53 \%)$. The area of primary forest has been slowly decreasing at a rate of $\sim 6 \mathrm{Mha} / \mathrm{yr}$ since the 1990s. This rate is especially high in Brazil and Indonesia; these two countries are responsible for the loss of 4.9 Mha of forests annually. Forest loss tends to occur in low-income countries (largely in the tropics), whereas higherincome countries have reversed their trend of forest reduction (Kirilenko \& Sedjo, 2007).

Converting rainforests, peatlands, savannas, or grasslands to areas used for biofuel production and food crops in Brazil, Southeast Asia, and the United States creates a "carbon debt" by releasing 17 to 420 times more $\mathrm{CO}_{2}$ than the annual greenhouse gas (GHG) reductions that these biofuels would provide by displacing fossil fuels. In contrast, biofuels from waste biomass or from biomass grown on marginal lands planted with perennial species incur little or no carbon debt (Fargione et al., 2008; Searchinger et al., 2008). Tropical deforestation is estimated to cause approximately one-quarter of anthropogenic carbon emissions, in addition to loss of biodiversity and environmental services. In Brazil, the Amazon forest has been cleared since the $1990 \mathrm{~s}$ at a gross rate of $\sim 25,000 \mathrm{~km}^{2} / \mathrm{yr}$ (for comparison, Belgium is 30,000 $\mathrm{km}^{2}$ ). Kindermann et al. (2008) estimated that a program providing a $10 \%$ reduction in deforestation from 2005 to 2030 could provide a reduction of 0.3-0.6 Gt of $\mathrm{CO}_{2}$ emissions per year and would cost approximately US\$ 0.4-1.7 billion/year (bn/yr) over 30 years. A 50\% reduction in deforestation from 2005 to 2030 could provide a reduction of 1.5-2.7 Gt of $\mathrm{CO}_{2}$ emissions per year and would cost US\$17.2-28.0 bn/yr. In comparison, illegal logging was estimated by the World Bank to result in losses of revenue to developing countries of US\$ 15 bn/yr (Agrawal et al., 2008). This suggests that better control of illegal logging would compensate for the loss of revenue caused by the reduction in deforestation.

Currently, it is thought that the protection and enhancement of the terrestrial carbon sink is the best way to engineer climate against deleterious evolution (Reay, 2007). Worldwide monitoring of each country's contributions to GHG emissions should therefore be given the highest priority (Yang \& Sirianni, 2010). In this spirit, the CarbonTracker is an integrated system for $\mathrm{CO}_{2}$ measurement that assesses the net $\mathrm{CO}_{2}$ exchange between the terrestrial biosphere and the atmosphere and that will be useful for the scientific community and for policymakers (Peters et al., 2007). However, to establish effective GHG-reduction, without which $\mathrm{CO}_{2}$ emissions will be soon unsustainable, governments need consistency and harmonization of policies. For example, it is the objective of the United Nations and other international organizations to raise the GDP/capita in developing countries to the same 
level as has been achieved in developed countries (e.g., US\$ 9,000/capita). However, such politics would result in an increase in yearly global $\mathrm{CO}_{2}$ emissions by a factor of 5 (Tomkiewicz, 2006) for the following reasons: (i) below the saturation level of US\$ 25, $000 /$ capita, there is a positive correlation between energy consumption per capita and purchasing power and (ii) the world average GDP/capita is US\$ 5,210 (Tomkiewicz, 2006). Increase in $\mathrm{CO}_{2}$ emissions will therefore have to be compensated for by one or more of the following: (i) an increase in the global area planted with forests; (ii) a change in the technological paradigm (such as a commitment to convert to solar energy); or (iii) a decrease in human population size. Actually, global warming because of the increased use of fossil fuels matches predator-prey equations (Lonngren \& Bai, 2008). The solutions to these equations are periodic in time. If humans continue to adhere to the current trends of fossil fuel consumption (as we have done since the beginning of the industrial revolution), we should observe large fluctuations in human population size in the future. Because earth and fossil fuel reserves are not infinite, the global-warming scenario leads (on a long timescale) to an eventual decrease in both the human population and the fossil fuel reserves, with the ultimate possibility being human extinction. Among catastrophic scenarios that could affect the human population because of climate change, we cite the prediction that one billion people could lack drinking water by 2050 if $\mathrm{CO}_{2}$ emissions are not drastically reduced (Parry et al., 2008).

\subsection{Greenhouse gases and their management}

The perturbation in atmospheric trace gases (e.g., $\mathrm{SO}_{2}, \mathrm{O}_{3}, \mathrm{CO}, \mathrm{CO}_{2}, \mathrm{CH}_{4}, \mathrm{NO}_{2}$, and CFCs, among others) is an important factor affecting climate change (Hopkin, 2007). In turn, climate change may promote changes in agricultural conditions that could have deleterious socioeconomic effects (Howden et al., 2007). Atmospheric trace gases have strong absorption bands in the infrared (IR) and interact with IR radiation emitted both by the earth's surface and the atmosphere. This directly influences the thermal structure of the atmospheric environment and contributes to the greenhouse effect. Gases such as $\mathrm{NH}_{3}, \mathrm{SO}_{2}$ and their derivatives have lifetimes of only a few days, but they can have significant effects on the atmosphere (Begum, 2005). Emissions of $\mathrm{N}_{2} \mathrm{O}$ and $\mathrm{CH}_{4}$ are currently the dominant contributors. Although $\mathrm{CO}_{2}$ is the main greenhouse gas in terms of volume, others must also be considered. In agricultural practices, the main culprit is nitrous oxide $\left(\mathrm{N}_{2} \mathrm{O}\right)$, significant quantities of which are released from cultivated fields (particularly with the intensive use of fertilizers) (Snyder et al., 2009; Ceschia et al., 2010; Mander et al., 2010). Because $\mathrm{N}_{2} \mathrm{O}$ is $>300$ times more potent as a GHG than is $\mathrm{CO}_{2}$, even modest volumes can have significant impacts on the overall balance (Cherubini, 2010).

Harnessing the carbon sequestration capabilities of the terrestrial biosphere has been recognized as a potentially powerful, yet relatively low-cost, tool to offset carbon emissions (Dorian et al., 2006) and models for that purpose have been investigated (Werner et al., 2010). However, terrestrial carbon sequestration has been considered insufficient for meeting more than $25 \%$ of the $\mathrm{CO}_{2}$ emissions reductions that are globally required by 2050 . Given that carbon sinks are the best currently available scenario, an emissions credit system has been established to provide $\mathrm{CO}_{2}$ emitters (companies or countries) with a means to satisfy the carbon liability associated with their release of carbon into the atmosphere. The emitter temporarily satisfies his liability by "storing" (for a fee) the equivalent carbon in a terrestrial carbon sink (such as a forest) (Sedjo \& Marland, 2003). This concept is the application of the 
"willing-to-pay" principle within the international economic market. More simply, the right to emit $\mathrm{CO}_{2}$ (in the form of a carbon credit) is compensated for by growing biomass that will sequester an equivalent amount of carbon. The marketing of carbon credits has been organized to allow for rewarding activities that result in the "permanent" immobilization of $\mathrm{CO}_{2}$ in a nongaseous form. Ultimately, a carbon fee has been proposed that would be paid by industrial countries (in proportion to their emission contributions to GHG) to developing countries; these countries could then invest them in carbon mitigation practices (such as establishing or maintaining forest sinks) (Jones, 2010). The Kyoto Protocol is now legitimating activities such as revegetation, forest management, cropland management, grazing-land management, and also carbon sequestration in deep crustal layers (such as oil fields and deep saline aquifers) for trading with carbon credits (United Nations Framework Convention on Climate Change [UNFCCC], 2002). Principles of justice in proposals and policy approaches to avoided deforestation are also being pursued (Okereke \& Dooley, 2010) through negotiations on Reducing Emissions from Deforestation and forest Degradation (REDD).

It has been estimated that the biological sink may attain a cumulative $\mathrm{CO}_{2}$ sequestration of $100 \mathrm{Gt}$ over the next 50-100 years, with most of it in forest systems. This implies the capture of 10-20\% from the anticipated net fossil fuel emissions until 2050 (Sedjo \& Marland, 2003). However, carbon sequestered in the terrestrial biosphere may lack permanence. Forests may be harvested for timber that can be used to produce short-lived products or may be cleared for other purposes. Wild fires can release large amounts of sequestered carbon. Farmers may return to agricultural practices that release carbon that was previously captured. In that sense, terrestrial carbon sequestration may simply represent a delay in the flow of fossil fuel carbon to the atmosphere. However, economic incentives for carbon sequestration should increase permanent sequestration. That is, wherever and whenever there are incentives (payments) for carbon-sequestration services, one would expect more sequestration to occur than if no payments were made (Johnston \& Holloway, 2007; Tollefson, 2008).

Carbon sequestration in living forests can be performed on lands with low productivity that are not suitable for agriculture or for intensive forestry and that are compatible with goals of biodiversity conservation over large areas. In contrast, to be economically viable, intensive crops for biofuels generally need land that is more productive. Intensive biofuel crops may compete with food production or even with the less-productive lands that are currently sheltering most of the earth's biodiversity (Huston \& Marland, 2003; Miles \& Kapos, 2008). For example, this phenomena has been observed in Brazil, Indonesia and Malaysia, where cattle, soybean, sugarcane and palm oil may compete with standing forest (Darussalam, 2007; Laurance, 2007; Malhi et al., 2008; Stone, 2007; Venter et al., 2008). In Indonesia, this competition has disastrous consequences for wildlife. To resolve this problem, the Kyoto protocol and subsequent versions should include "wildlife credits" (in addition to carbon credits) to sustain wildlife and its buffering effect on human activities (Lovelock \& Margulis, 1974). This strategy would have the advantage of recognizing the fundamental roles played by ecosystem services and to begin to account for them (Mäler et al., 2008). New financial incentives are needed to act as a countervailing force to the economic pressures for deforestation (Jones, 2010). The recent agreement known as the "Bali Roadmap", which aims to extend the Kyoto Protocol beyond 2012, includes directives for providing compensation to rainforest-holding nations in exchange for control of deforestation and environment degradation. Such compensation could be managed either through international carbon markets or through voluntary funds. These directives have the potential to shift the balance of underlying economic market forces that currently favor deforestation by raising billions 
of dollars to pay for the ecosystem services provided by rainforests. However, to be effective they will require exceptional planning, execution and long-term follow-through. The new proposal also aims to reduce EU CO 2 emissions by $30 \%$ by 2020 if a global climate deal is reached in international negotiations (if not, the cut will be 20\%) (Schiermeier, 2008). The EU is also planning to protect its economy against carbon "dumpers" by applying leverage that aims to force companies that import goods from polluting countries to buy emissions permits (Barnet, 2008).

Typically, carbon-credit compensation funds are used in developing countries for establishing new long-term plantations (such as rubber trees or oil palm). One difficulty is that the actual goal of carbon sequestration can be negated in cases where the renter first illegally burns the original forest, earns the carbon-credit funds and subsequently establishes a new plantation that will never be as productive, in terms of carbon sequestration, as the original forest. In some regions, environmental crimes are not easily detected and may also not be "significantly" punished. Key recommendations to ensure the environmental sustainability of biofuels through certification (including international approaches and global monitoring) should help to control the process (Scarlat \& Dallemand, 2010). Despite these problems, the carbon-credit market was stabilized as of 2007 and is not expected to collapse any further (Haag, 2007). The next few years represent a unique opportunity (perhaps the last) to maintain the resilience of biodiversity and ecosystem services (Malhi et al., 2008; García-Montero et al., 2010; Hagerman et al., 2010).

\subsection{Why biofuels?}

Compared with an array of solar cells, plants are strikingly poor transducers of the sun's energy. Energy storage by photosynthesis is approximately $<2$ watts $(W)$ per $\mathrm{m}^{2}$. The important difference between plants and solar cells is that plants are very cheap. They are able to grow with a moderate supply of water, nutrients and $\mathrm{CO}_{2}$ that they turn into stable organic compounds. No fuel technology is perfect, but the GHG crisis and concern over oil supplies means that diversifying the range of fuel options makes good sense; at the very least, such diversification places humanity on a healthy learning curve (Haug et al., 2011). Continuous increases in energy needs have encouraged governments to search for new alternatives to fossil fuels. The rationale is to facilitate the transition from a fossil-energy based economy to an economy based on renewable sources of energy. Numerous lowemission scenarios have demonstrated that the goals of the Kyoto Protocol cannot be achieved without providing a large role for biofuels by 2050 in the global energy economy. Among the reasons why biofuels are appropriate for such a transition are the following: (i) their simplicity; (ii) their production via well-known agricultural technologies; (iii) their potential for mitigation of climate warming without complete restructuring of the current working energy system; (iv) the use of existing engines for their transportation (even considering the conventional turbofan used in aviation) (Kleiner, 2007; Rothengatter, 2010); (v) their potential to facilitate worldwide mobilization around a common set of regulations; (vi) their potential as a directly available energy source with good public acceptance; (vii) their more uniform distribution than the distributions of fossil fuel and nuclear resources; and (viii) their potential to create benefits for rural areas, including employment creation.

\subsection{What are biofuels?}

The term biofuel refers to liquid, gas and solid fuels that are predominantly produced from biomass. The production of biofuels may ignite concerns about security, the environment, 
trading, and socioeconomic issues related to the rural sector. Biofuels include bioethanol, biomethanol, vegetable oils, biodiesel, biogas, bio-synthetic gas (bio-syngas), bio-oil, biochar (charcoal created by biomass pyrolysis), Fischer-Tropsch liquids and biohydrogen. Biogas and bio-oil are primary products, the preliminary processing of which is almost reduced to collecting the raw material. Most traditional biofuels (such as ethanol from corn, wheat, or sugar beets and biodiesel from oil seeds) are produced from classic agricultural food crops that require high-quality agricultural land for growth. The biofuel economy will grow rapidly during the $21^{\text {st }}$ century (Demirbas, 2008a).

\subsubsection{Biogas}

There are two basic procedures for transforming solid biomass into liquid or gaseous biofuels. The first is to transform it by microbiological fermentation (Gavrilescu \& Chisti, 2005) (i.e., to convert the polysaccharides into alcohols such as bioethanol or biobutanol) or to convert raw plant biomass by anaerobic fermentation into biomethane (Demirbas \& Balat, 2006). One of the main drawbacks of the anaerobic system is that it is slow (because of the small amount of energy that is available to the organisms). Therefore, the amount of methane that can be produced is limited and this technology is only sustainable under selected scenarios (Asam et al., 2011). However, the introduction of even a small installation for transforming agricultural and human wastes into methane can have an enormous effect on the living standards of small communities (Arthur et al., 2011; Parker, 2002).

The second procedure aims to thermochemically convert the total biomass into a synthesis gas of high calorific value (also called syngas, i.e., $\mathrm{H}_{2}+\mathrm{CO}$ ) with subsequent production of various liquid and gaseous fuels (Tijmensen et al., 2002). The production of syngas is a potential area for large-scale $\mathrm{CO}_{2}$ conversion and utilization. The reforming of $\mathrm{CO}_{2}$ to $\mathrm{CH}_{4}$ has been extensively studied and reported on in the literature (Song \& Pan, 2004). The catalytic reduction of $\mathrm{CO}_{2}$ to form methanol (or even $\mathrm{CH}_{4}$ ) using renewable energy sources could become a viable alternative to scarce or expensive fossil resources.

Biodiesel from plant oils and bioalcohol from sugar use only a portion of the total biomass. Next-generation processes are being developed to convert biomass to syngas (Baker \& Keisler, 2011; Fagernäs et al., 2010) that can then be converted into fuels or chemicals by a synthetic process (the so-called Fischer-Tropsch, or FT, process).

$$
\begin{gathered}
\mathrm{CH} 0.8+0.7 \mathrm{O}_{2} \rightarrow \mathrm{CO}+0.4 \mathrm{H}_{2} \mathrm{O} \\
\mathrm{CH} 0.8+\mathrm{H}_{2} \mathrm{O} \rightarrow \mathrm{CO}+1.4 \mathrm{H}_{2} \\
\mathrm{CO}+\mathrm{H}_{2} \mathrm{O} \rightarrow \mathrm{CO}_{2}+\mathrm{H}_{2} \\
(2 \mathrm{n}+1) \mathrm{H}_{2}+\mathrm{nCO} \rightarrow \mathrm{CnH}_{2 \mathrm{n}+2}+\mathrm{nH}_{2} \mathrm{O}
\end{gathered}
$$

Considering that coal inputs supply a 0.8 to 1 ratio of $\mathrm{H} / \mathrm{C}$, the whole FT process can be briefly written as follows. The partial oxidation of coal by oxygen gives equation (1). The interaction of water with carbon monoxide through "steam reforming" produces equation (2). Subsequently, the H/CO ratio is improved by "shifting" (transferring) the oxygen from the molecular water to $\mathrm{CO}$, producing an additional hydrogen and carbon dioxide following equation (3). After removing the sulfur and carbon dioxide contaminants, the syngas is 
reacted over a catalyst in the FT reactor to produce high-quality clean fuels following the formula (4) (Greyvenstein et al., 2008).

Biomass is more reactive than coal and (depending on the technology) is usually gasified at temperatures of between $5500^{\circ} \mathrm{C}$ and $1,500{ }^{\circ} \mathrm{C}$ and at pressures varying between 4 and 30 bars (Damartzis \& Zabaniotou 2011; Leibold et al., 2008; Steinberg, 2006). Typically, biomass is burned in an electrically heated furnace consisting of several multiple-tube units that can be heated separately up to $1,350^{\circ} \mathrm{C}$ (Theis et al., 2006). Alternatively, the conversion of fossil fuel or biomass can be performed in hydrogen plasma. The temperature induced by an electric arc in hydrogen plasma is very high $\left(\sim 1,500{ }^{\circ} \mathrm{C}\right)$; therefore, this technology produces hydrogen and CO gas with a conversion rate of near 100\% (Steinberg, 2006). FT synthesis generates intermediate products for synthetic fuels (Liu et al., 2007). The thermal efficiency of producing electricity and hydrogen through hydrogen plasma and carbon fuel cells varies from $87 \%$ to $92 \%$, depending on the type of fuel and the biomass feedstock. This is more than twice as efficient as a conventional steam plant that burns coal and generates power with a $\sim 38 \%$ efficiency. In addition, coupling hydrogen plasma and carbon fuel-cell technologies allows for a $75 \%$ reduction in $\mathrm{CO}_{2}$ emission per unit of electricity (Steinberg, 2006).

Because FT produces predominantly linear hydrocarbon chains, this process is currently attracting considerable interest. FT has already been applied on a commercial scale by Sasol, Petro S.A. and Shell, mainly to produce transportation fuels and chemicals (the feedstock being coal or natural gas). This fuel option has several notable advantages. First, the FT process can produce hydrocarbons of different lengths (typically <C15, Liu et al., 2007) from any carbonaceous feedstocks; these hydrocarbons can then be refined to easily transportable liquid fuels. Secondly, because of their functional similarities to conventional refinery products, the synthetic fuels (synfuels) produced by the FT process (i) can be handled by existing transportation systems; (ii) can be stored in refueling infrastructure for petroleum products; (ii) are largely compatible with current vehicles; and (iv) can be blended with current petroleum fuels (Tijmensen et al., 2002). Thirdly, synfuels are of high quality (this is especially true for FT diesel), have a very high cetane number and are free of sulfur, nitrogen, aromatics, and other contaminants typically found in petroleum products. The principal drawbacks of the FT process are that the capital cost of FT-conversion plants is relatively high and that the energy efficiency for the production of FT liquids by conventional techniques is lower than the energy efficiency for the production of alternative fuels (Takeshita \& Yamaji, 2008).

\subsubsection{Bio-oil}

Bio-oils are dark red-to-black liquids that are produced by biomass pyrolysis. Biomass is typically obtained from municipal wastes or from agricultural and forestry by-products (Demirbas, 2007). With an efficiency rate as high as $\sim 70 \%$, pyrolysis is among the most efficient processes for biomass conversion. The density of the liquid is approximately 1,200 $\mathrm{kg} / \mathrm{m}^{3}$, which is higher than that of fuel oils and significantly higher than that of the original biomass. The gasification of bio-oil with pure oxygen and the further processing of syngas into synthetic fuel by the FT process, is being investigated; however, this process does not appear to be economically attractive (Demirbas \& Balat, 2006).

\subsubsection{Plant oils}

There has been interest in the use of virgin plant oils to fuel diesel engines. At least 2,000 oleaginous species, growing in almost all climates and latitudes, have been identified. There 
are more than 350 plant species that produce oil that could be used to power diesel engines (Goering et al., 1982). The plant oils are made up of $98 \%$ triglycerides and small amounts of mono- and diglycerides. There are basically two types of vegetable oils: those in which the majority of fatty acids are in $\mathrm{C} 12$ (e.g., palms) and those in which the majority of fatty acids are in C18.

The direct use of plant oils (and/or blends of these oils with fossil fuels) has generally been considered to be unsatisfactory or impracticable for both direct and indirect diesel engines. Obvious problems include their high viscosity (Ramadhas et al., 2005), acidic composition, free fatty acid content, tendency to deposit carbon, tendency for lubricating-oil thickening, and gum formation because of oxidation polymerization during storage and combustion. When blending vegetable oils with fossil diesel fuel, the viscosity can be extensively adjusted. Based on EN 14214 recommendations, the maximum blending rate of most vegetable oils is B30 (30\% plant oil/fossil diesel, v/v) (Abollé et al., 2008). The oil viscosity (because of the presence large triglycerides) can also be reduced by pyrolysis, which produces an alternative fuel for diesel engines (Lima et al., 2004). Using plant oils in blends also significantly increases their cloud points and thus limits their use to climatically compatible countries.

\subsubsection{Bioalcohol}

Because of the energy crisis and climate warming, humanity faces the need for a huge shortterm supply of biofuels (see below). Bioethanol and biodiesel have been considered the best candidates for satisfying these needs and are what we consider the first generation of biofuels. Ethanol can be produced from a range of crops including sugarcane, sugar beets, maize, barley, potatoes, cassava, and mahua (Baker \& Keisler 2011; Kremer \& Fachetti 2000). Flexible-fuel motors have been developed that can burn hydrous ethanol/gasoline blends in any combination, including pure ethanol. The automatic adjustment of combustion parameters is controlled electronically in these engines as a function of the oxygen level needed by the fuel in the tank (Marris, 2006). The so-called "gasohol" is a blend of ethanol and gasoline. Ethanol is produced via fermentation of a sugar slurry that is typically prepared from sugar or grain crops. The action of yeast on the sugar produces a solution that contains approximately $12 \%$ ethanol. The yeast invertase catalyzes the sucrose hydrolysis into glucose and fructose. Subsequently, yeast zymase converts the glucose and the fructose into ethanol. The alcohol can then be concentrated by distillation to produce up to $96 \%$ ethanol (hydrous ethanol).

Ethanol is a polar solvent and its chemistry is very different from that of hydrocarbon fuels (which are non-polar solvents). As a result, blending ethanol into hydrocarbon fuels introduces some specific challenges. These challenges include (i) higher fuel volatility at low rates of ethanol/gasoline blends, (ii) higher octane ratings, (iii) an increase in dissolvedwater content in motor gasoline that promotes heterogeneity of fuel blends and resulting engine corrosion and (iv) higher solvency. However, Akzo Nobel Surface Chemistry and the Lubrizol Corporation have developed and produced a low cost additive that makes it possible to blend ethanol with diesel fuel to obtain a stable and clear fuel (Lü et al., 2004). This fuel is called "Dieshol".

Biomethanol can be produced from biomass using bio-syngas obtained from the steamreforming processing of biomass. Biomethanol is considerably easier to recover from biomass than is bioethanol. However, sustainable methods of methanol production are not currently economically viable. The production of methanol from biomass is a cost-intensive 
chemical process. Therefore, under current conditions, only waste biomass, such as wood or municipal waste, is used to produce methanol.

\subsubsection{Biodiesel}

Biodiesel has the advantage that it can be used in any diesel engine without modification. It is produced by the transformation of renewable oils, such as those synthetized by plants, algae, bacteria and fungi. First-generation biodiesel is considered to be the result of a twostage process that involves (i) the crushing of raw material (typically oilseeds) in specialized mills to expel the oils and (ii) the transformation of oil into biodiesel. Free fatty acids (FFA) or triglycerides are converted into alkyl-esters by reaction with short-chain alcohols (such as methanol or ethanol) in the presence of a catalyst. The reaction involved in the conversion of FFA to alkyl-esters is called esterification, whereas that involved in the conversion of triglycerides is called transesterification. Fatty acid methyl-esters are only partly biological, as the methanol involved is generally produced from fossil methane (natural gas). However, biodiesel can also be produced by replacing methanol with ethanol, resulting in fatty acid ethyl-esters. If the ethanol is of biological origin, the product is fully biological. The purpose of the transesterification process is to lower the viscosity of the oil with transesterification being less expensive than the pyrolysis that is used in bio-oil processing. According to the EU standards for alternative diesel fuels, alkyl-esters in biodiesel must be $\geq 96.5 \mathrm{wt} \%$.

\subsubsection{The four generations of biofuels}

The first generation of biofuels demonstrated that energy crops are technically feasible, but that no single solution exists to cover every situation (Venturi \& Venturi, 2003). In addition, the production of first-generation biofuels is complicated by issues that are contrary to biofuel philosophy, such as the destruction of tropical rainforests (Kleiner, 2008). Tropical rainforests are the most efficient carbon sinks on earth. Therefore, if biofuels contribute to their destruction, this implies that the carbon balance of biofuels is negative. This consideration limits the viability of first-generation biofuels. It also comes with the corollary that raw materials for biofuel production will have to be diversified over the long term. Second-generation bioethanol is precisely an attempt to overcome this challenge.

Second-generation bioethanol will be produced from lignocellulosic biomass, which is a more suitable source of renewable energy (Frondel \& Peters, 2007; Tan et al., 2008; Tilman et al., 2007). Lignocellulose is obtained from inexpensive cellulosic biomass that is encountered throughout the world. However, the low-cost transformation of lignocellulose into bioethanol is still challenging. Some possible technologies involve genetic modification of plants, which is a source of concern for society. Whatever the future evolution of the technology, the introduction of energy policies is crucial to ensure that biomass ethanol is effectively developed to become a major source of renewable energy (Tan et al., 2008).

Algae and cyanobacteria are far more efficient than higher plants in capturing solar energy and will surpass first- and second-generation biofuels in terms of energy capture per unit of surface area (Brennan \& Owende, 2010). Algae are already used in pilot $\mathrm{CO}_{2}$-sequestration units for emissions cleaning in some conventional power plants running on fossil fuels. This technique is called $\mathrm{CO}_{2}$ filtration. Unfortunately, algae require capital for investing in reactors that can grow them, making $\mathrm{CO}_{2}$ filtration an excellent opportunity for developing this technology. In that sense, algae can be regarded as a third-generation fuel. New methods and technologies for the production of second- (such as synfuels, Baker \& Keisler, 2011) and 
third-generation biodiesel fuels are being developed and will result in the modification of the definition of biofuels that is generally used in government regulations (Lois, 2007).

Finally, one can also envision the exploration of photosynthetic mechanisms for biohydrogen and bioelectricity production. These would constitute fourth-generation biofuels (Gressel, 2008). The development of effective fourth-generation biofuels is not expected before the second half of the $21^{\text {st }}$ century.

\section{Plant biofuels}

\subsection{Bioethanol}

The technique of alcohol fermentation has been known for thousands of years. Ethanol distillation has been carried out for decades by industry because it has been part of the process of the regulation of sugar prices on the international market. Ethanol is regularly produced from the isomerose (high-fructose syrup) of grain crops such as maize or wheat and from sugar crops such as sugar beet or sugarcane. In Europe, sugar beet is preferred. This is especially true in countries such as the UK, France, Holland, Belgium and Germany, where it is highly productive, as 1 ha of this crop can produce $5.5 \mathrm{t}$ of ethanol, ( 1 ha of wheat only produces $2.5 \mathrm{t}$ of ethanol) (Demirbas \& Balat, 2006). These numbers must be compared to the ethanol production from sugarcane, which reaches $7.5 \mathrm{t}$ in Brazil (Bourne, 2007).

The USA produces ethanol from corn, whereas India uses sugarcane, China uses sweet potatoes and Canada uses wheat. Countries such as China, Austria, Sweden, New Zealand, and even Ghana are now building their biofuels infrastructure around wood-based feedstocks (Herrera, 2006).

The growing area used for sugarcane production in Brazil accounts for 8 Mha (Brazil is 850 Mha). Sugarcane produces an eight-fold return on the energy that is used to produce it. One ton of sugarcane used for ethanol production represents a net economy in $\mathrm{CO}_{2}$ emissions equivalent to 220.5 when compared with fossil fuel. Thus, if rain forest is not destroyed to grow the sugarcane, ethanol from Brazilian sugarcane reduces greenhouse gas emissions by the equivalent of $25.8 \mathrm{Mt} \mathrm{CO}_{2} / \mathrm{yr}$ (Marris, 2006; Walter et al., 2010). Fortunately, the Amazon, the Pantanal and the Alto Rio Paraguai regions have been prohibited for sugarcane cultivation by government decree since 2009 to preserve these ecosystems. In 2009, ethanol accounted for approximately $47 \%$ of transport fuel used in Brazil. The "Flex" car fleet can use $100 \%$ of either ethanol or gasoline (Orellana \& Neto, 2006). In fact, ethanol gives $20 \%$ to $30 \%$ fewer kilometers per liter than does gasoline and people adapt the blend in proportion to the best consumption/price ratio (Marris, 2006).

The ethanol export capacity of Brazil is currently $\sim 8 \mathrm{Gl}$. The export-destination countries are mainly the US, the EU, Japan and Central America. Conservative estimates suggest that the area used for sugarcane production in Brazil should increase from 8 to 11 Mha by 2015. By government decree, the maximum possible area to be used for sugarcane cultivation has been limited to 64 Mha (i.e., $18.5 \%$ of national territory). In the short-to-medium term, Brazil is the only country that is able to sustain the emerging international ethanol market. For long-term establishment in the market, other countries, such as Australia, Columbia, Guatemala, India, Mexico and Thailand, will need to increase their exports (Orellana \& Neto, 2006).

Brazil began ethanol production in 1973. At that time, it was heavily dependent on foreign crude oil, with nearly $80 \%$ of its oil being imported. It launched the program PROALCOOL in 1975 (Goldemberg et al., 2004) and began to offer subsidies and low-interest loans to 
bioethanol producers to increase existing capacity. A policy of price dumping was maintained by the government to boost the use of gasohol. The ethanol content of common gasoline was originally $5 \%$ and is now $25 \%$ by law (Pousa et al., 2007).

\subsubsection{Bioethanol from lignocellulosic biomass}

The most abundant sources of renewable carbon in the biosphere are plant structural polysaccharides. Approximately $1,011 \mathrm{t}$ of these polymers (with an energy content equivalent to $640 \mathrm{Gt}$ of oil) are synthesized annually (Proctor et al., 2005). For example, nonfood plant species for bioenergy production include Sorghum halepense, Arundo donax, Phalaris arundinacea (Raghu et al., 2006), poplar, switchgrass (Panicum virgatum), the hybrid grass Miscanthus $\mathrm{x}$ giganteus and big bluestem. These species are considered to have energetic, economic and environmental advantages over first-generation biofuel crops (Hill et al., 2006; Havlík et al., 2010). Switchgrass, for example, produces a net energy of 60 Giga Joule per hectare and per year (GJ/ha/yr) (Schmer et al., 2008). The potential terrestrial fuel yield from cellulosic biomass production $(135 \mathrm{GJ} / \mathrm{ha} / \mathrm{yr})$ is somewhat higher than that from corn (85 GJ/ha/yr) or soybean biodiesel (18 GJ/ha/yr). The optimal types of specialized biofuel crops are likely to be perennial and indigenous species that are well adapted for growth on marginal lands.

In tropical and Mediterranean countries, eucalyptus is a fast-growing woody species that is cultivated for biomass production. In wet and temperate countries, high-yielding varieties of willow (Salix nigra), Miscanthus (a high-yielding rhizomatous grass that yields up to $26 \mathrm{t}$ of dry matter/ha/yr) and poplar are available. These energy crops require relatively low chemical and energy inputs compared with conventional crop production and they are able to grow on marginal lands (thus avoiding the problem of competition with food crops). Considering an Ireland-based scenario, the utilization of Miscanthus and willow for heat and electricity generation would allow for savings of as much as 5.2\% of 2004 GHG emissions while using only $4.6 \%$ of the total agricultural area (Styles \& Jones, 2008). It has been estimated that lignocellulosic biomass could contribute 70-100 exajoules ( 1 exajoule $=$ 1,000,000,000 gigajoules) by 2020 (Gielen et al., 2002).

Poplar is a candidate for short rotations of $\sim 5$ years. Poplar disperses its seeds and pollen much farther than do other crops, it does so for many years before harvesting and it has many wild relatives with which it can outcross. In addition, poplar can be multiplied vegetatively, which would allow for the valorization of low-lignin transformants through the multiplication of sterile accessions. The biotechnology of poplar has been dominated for several years and its genome has been sequenced.

Trees not only can achieve a lignocellulosic energy-conversion factor of 16 (compared with 1-1.5 for corn and 8-10 for sugarcane), but they can also be grown on marginal lands, thus reducing competition with food crops.

The world consumption of wood is $3.4 \mathrm{Gm}^{3} / \mathrm{yr}$ and will substantially increase with the production of ethanol from biomass. The development of high-yield plantations is essential to sustain the increased demand for wood (Fenning et al., 2008). Small towns, schools, buses, ski resorts and factories in Sweden and Austria have long relied on the byproducts of the forest industry to produce liquid and solid fuel (Herrera, 2006).

Biotechnology and systems biology can be envisaged for plant breeding. Many plant species used for bioenergy production are wild to semi-domesticated. Molecular approaches can speed up domestication and productivity (Chen \& Dixon, 2007). 
A number of candidate genes for domestication traits have been identified by comparing the genomes of poplar, rice and Arabidopsis for large-scale gene function and expression. The genes investigated were involved in synthesis of cellulose and hemicellulose, as well as in various morphological growth characteristics (such as height, branch number and stem thickness) (Ragauskas et al., 2006; Chapple et al., 2007; Sticklen, 2008). Transgenic plants that overexpressed mutant alleles or showed RNA interference (RNAi) for silencing endogenous genes have been designed and cell-wall components that were more easily converted to ethanol have been obtained (Chen \& Dixon, 2007; Himmel et al., 2007). Examples of these strategies include the complementary decrease of lignin and the increase of cellulose components in cell walls or the directed overexpression of cellulases in plant cells to drastically decrease the cost of cell wall conversion to ethanol (Sticklen, 2008). However, the strategy involving lignin interference must be evaluated carefully in the context of biomass production because it could have side effects such as excessive sensitivity to fungal pathogens.

Because lignin is relatively resistant to enzymatic degradation, low-lignin transgenic trees have been investigated (Herrera, 2006). RNAi-mediated suppression of p-coumaroyl-CoA 3'-hydroxylase in hybrid poplars generally correlated very well with the reduction of lignin content. Up to $\sim 13.5 \%$ more cell-wall carbohydrates have been observed in the suppressed lines as compared to wild-type poplars (Coleman et al., 2008).

Currently, lignocellulose pretreatment followed by enzymatic hydrolysis is the key process used for the bioconversion of lignocellulosic biomass (Sanderson, 2006). The type of pretreatment defines the optimal enzyme mixture to be used and the composition of the sugar mixture that is produced. Finally, the sugars are fermented with ethanol-producing microorganisms such as yeasts, Zymomonas mobilis, Escherichia coli, or Pichia stipitis (Fischer et al., 2008).

\subsection{Biodiesel}

\subsubsection{The process of biodiesel production}

The main components of plant oils are the fatty acids and their derivatives the mono-, diand triacylglycerides. Tri-acylglycerides make up $95 \%$ of plant oils. Glycerides are esters formed by fatty acid condensation with tri-alcohol glycerol (propanetriol). Depending on the number of fatty acids fixed on the glycerol molecule, one can have mono-, di- or triacylglycerides. Of course, the fatty acids can be the same or different. As stated in the introduction, biodiesel can be obtained by esterification or transesterification. Esterification is the process by which a fatty acid reacts with a mono-alcohol to form an ester. The esterification reaction is catalyzed by acids. Esterification is commonly used as a step in the process of biodiesel fabrication to eliminate FFAs from low-quality oil with high acid content. Transesterification (or alcoholysis) is the displacement of alcohol from an ester by another alcohol in a process similar to hydrolysis. This process has been widely used to reduce triglyceride viscosity. The transesterification reaction is represented by the general equation (5).

$$
\mathrm{RCOOR}^{\prime}+\mathrm{R}^{\prime \prime} \mathrm{OH} \rightarrow \mathrm{RCOOR}{ }^{\prime \prime}+\mathrm{R}^{\prime} \mathrm{OH}
$$

This stepwise reaction occurs through the successive formation of di- and monoglycerides as intermediate products (Canakci et al., 2006). Theoretically, transesterification requires three alcohol molecules for one triglyceride molecule; however, an excess of alcohol is necessary because the three intermediate reactions are reversible (Marchetti et al., 2007; Om 
Tapanes et al., 2008). After the reaction period, the glycerol-rich phase is separated from the ester layer by decantation or centrifugation. The resulting ester phase (crude biodiesel) contains contaminants such as methanol, glycerides, soaps, catalysts, or glycerol that must be purified to comply with the European Standard EN 14214.

Different technologies can be used for biodiesel production; these include chemical or enzyme catalysis and supercritical alcohol treatment (Demirbas, 2008b). EN 14214 establishes 25 parameters that must be assessed to certify the biodiesel quality.

In conventional transesterification and esterification processes for the production of biodiesel, strong alkalis or acids are used as chemical catalysts. These processes are highly energy consumptive and the poor reaction selectivity that often results from the physicochemical synthesis justifies the ongoing research on enzymatic catalysis. In addition, an extra purification step is required to remove glycerol, water, and other contaminants from alkyl-esters.

The base catalysis is much faster than the acid catalysis. Low cost and favorable kinetics have turned $\mathrm{NaOH}$ into the most-used catalyst in the industry. However, soap and emulsion can be formed during the reaction and complicate the purification process.

\subsubsection{Non-edible feedstocks for biofuel production}

Currently, approximately $84 \%$ of the world biodiesel production is met by rapeseed oil. The remaining portions are from sunflower oil (13\%), palm oil (1\%), soybean oil and others $(2 \%)$ (Gui et al., 2008). More than $95 \%$ of biodiesel is still made from edible oils. To overcome this undesirable situation, biodiesel is increasingly being produced from non-edible oils and waste cooking oil (WCO). Non-edible oils offer the advantage that they do not compete with edible oils on the food market.

Used cooking oil is a waste product, and for that reason, it is cheaper than virgin plant oil. The higher initial investment required by the acid-catalyzed process (stainless-steel reactors and methanol-distillation columns) is compensated for by low feedstock cost (Zhang et al., 2003). Reusing WCO esters provides an elegant form of recycling, given that waste oils are prohibited for use in animal feed, are harmful to the environment, and human health and disrupt normal operations at wastewater treatment plants (increasing the costs of both maintenance and water purification). The production of biodiesel from WCO is still marginal, but it is increasing worldwide. The USA and China are leaders in WCO use, with 10 and 4.5 Mt/yr, respectively. Other countries and regions, such as the EU, Canada, Malaysia, Taiwan and Japan, produce approximately 0.5-1 Mt/yr (Gui et al., 2008). The potential use of $\mathrm{WCO}$ as a primary source for biodiesel fuel is important because such use would negate most of the actual concerns regarding the competition of food and biodiesel crops for land (Bindraban et al., 2009; Odling-Smee 2007). By converting edible oils into biodiesel fuel, food resources are actually being converted into automotive fuels. It is believed that large-scale production of biodiesel fuels from edible oils may bring global imbalance to the food supply-and-demand market, even if such a trend has been contested (Ajanovic, 2010). However, nothing prevents the use of edible oils first for cooking and then for biodiesel fuel.

\subsubsection{Biofuel feedstocks in the world}

Concerned by potential climate change-related damages (including changes to coastlines and the spread of tropical diseases, among others), the US faces the necessity of finding solutions for the $17.7 \%$-reduction of GHG emissions (Lokey, 2007). Because of the fact that 
the electrical sector accounts for $40 \%$ of all GHG emissions, investments in cost-competitive renewable energy sources, such as wind, geothermal and hydroelectricity, have been recommended. Given the ample solar resources that exist in the US, it has a plethora of untapped sources for renewable-energy generation (Flavin et al., 2006). The Biomass Program of the US Department of Energy (launched in 2000) recommended 5\% use of biofuels by $2010,15 \%$ by 2017 , and $30 \%$ by 2050 . However, it is predicted that the ethanol market penetration for transportation should attain $\sim 50 \%$ of gasoline consumption by 2030 (Szulczyk et al., 2010). Currently, maize and other cereals (such as sorghum) are the primary feedstocks for US ethanol production. At $40 \mathrm{Ml}$ of ethanol per day, maize is still considered a low-efficiency biofuel crop because of its high required input, excessive topsoil erosion (10 times faster than sustainable) and other negative side effects (Donner \& Kucharik, 2008; Laurance, 2007; Sanderson, 2006; Scharlemann \& Laurance, 2008). By comparison, biodiesel from soybean requires lower inputs. However, neither of these biofuels can displace fossil fuel without impacting food supplies. Even if all US corn and soybean production were dedicated to biofuels, only $12 \%$ of the gasoline and $6 \%$ of the diesel demand, respectively, would be met (Hill et al., 2006). However, agricultural, municipal, and forest wastes could together sustainably provide $1 \mathrm{Gt}$ of dry matter annually and should complement the other biofuel crops (Vogt et al., 2008). It was proposed that 3.1-21.3 Mha of land should be converted to biomass production (Schmer et al., 2008). Algal biodiesel is also being included in an integrated renewable-energy park (Singh \& Gu, 2010; Subhadra, 2010).

Bioethanol from Brazil results in over 90\% GHG savings (Hill et al., 2006). In addition to the PROALCOOL program, the Brazilian government created the PRO-ÓLEO program in 1980 and expected a $30 \%$ mixture of vegetable oils or derivatives in diesel and full substitution in the long term. Unfortunately, after the price drop of crude oil on the international market in 1986 , this program was abandoned and was only reintroduced in 2002. Because of its great biodiversity and diversified climate and soil conditions, Brazil has a variety of plant-oil feedstocks, including mainly soybean, sunflower, coconut, castor bean, cottonseed, oil palm, physic nut and babassu (Nass et al., 2007). Brazil celebrated the inauguration of the Embrapa Agroenergia research center in 2010 to promote the integration of the oil from these feedstocks into the network of biodiesel sources. The National Program of Production and Use of Biodiesel (PNPB) was launched in 2004 with the objective of establishing the economic viability of biodiesel production together with social and regional development. The current diesel consumption in Brazil is approximately $40 \mathrm{Gl} / \mathrm{yr}$ and the potential market for biodiesel currently of $800 \mathrm{Ml}$ and that should achieve $2 \mathrm{Gl}$ by 2013. In addition, B5 has been mandatory since 2010. Auction prices have varied between US\$ 0.3 and $0.8 / 1$ according to the area of production (Barros et al., 2006). Between 1975 and 1999, US\$ 5 bn were invested in bioenergy resulting in the creation of 700,000 new jobs and US\$ 43 bn saving in gasoline imports (Moreira \& Goldemberg, 1999). The rate of job creation related to biodiesel production has been estimated to be 1.16 jobs/Ml of annual production (Johnston \& Holloway, 2007). However, the recent trend of business centralization is expected to reduce this rate (Hall et al., 2009). Petrobras is now processing (with a capacity of 425,000 $\mathrm{t}$ ) a mixture of plant oil and crude oil under the name of "H-Bio". With a tropical climate in the major part of its extention, the country has a potential 90 Mha that could be used for oleaginous crop production and that extends over Mato Grosso (southwest), Goiás, Tocantins, Minas Gerais (center), Bahia Piauí, and Maranhão (northeast).

The EU accounts for 454 million people (i.e., $7 \%$ of the world's population and $50 \%$ more people than live in the US) (Solomon \& Banerjee, 2006). The EU is dedicated to a long-term 
conversion to a hydrogen economy. Renewable energy sources and eventually advanced nuclear power, are envisioned as the principal hydrogen sources on the horizon for use in 2020-2050 (Adamson, 2004). However, even for the distant future, the EU foresees hydrogen production from fossil fuels with carbon sequestration still playing a major role (together with renewable energy and nuclear power). Because of their renewability, biodiesel and bioethanol in the EU have been calculated to result in 15-70\% GHG savings when compared to fossil fuels. Frondel and Peters (2007) found that the energy and GHG balances of rapeseed biodiesel are clearly positive.

Bioethanol from sugar beets or wheat and biodiesel from rapeseed are currently the most important options available to the EU for reaching its target biofuel production. Because of increased land use for biofuel production, biofuel crops are now competing with food crops (Odling-Smee, 2007) and they are expected to have substantial effects on the economy. The European consumption of fossil diesel fuel is estimated to be approximately $210 \mathrm{Gl}$ and that of biodiesel to be $9.6 \mathrm{Gl}$ (Malça \& Freire, 2011). The EU produces over $\sim 2$ Mha (i.e., $~ 1 \mathrm{Gl}$ ) of rapeseed $(0.5 \mathrm{kl} / \mathrm{ha})$ and sunflower $(0.6 \mathrm{kl} / \mathrm{ha})$ (Fischer et al., 2010), which shows that it depends heavily on importation of biofuels to approach the recommended target of B5.75. Given the higher energy potential of synfuel from biomass and the constraints on the availability of arable land, second-generation biofuels should soon enter the race for biofuel production (Fischer et al., 2010; Havlík et al., 2010).

The price for biodiesel that meets the EU quality standard (EN 14214) is approximately $€$ $730 / \mathrm{t}$. By subtracting the biodiesel export value from the EU market price, one obtains the profit obtained by selling biodiesel from abroad on that market. The export value includes production and exportation costs. Production costs are made up of the plant oil or animal fat production plus the biodiesel processing minus the value of by-products (glycerol for example). Exportation costs include scaling, insurance, taxes and administrative costs (see the calculations in Johnston \& Holloway, 2007). The price of US\$ 0.88/1 for biodiesel was $45 \%$ higher than the price of fossil diesel fuel during the same period (2006). Although this price is a convenient baseline, the biodiesel price on the EU market can change quickly depending on factors such as current domestic production, fossil diesel-fuel prices, agricultural yields, and legislation. The same rules will apply to emerging markets in China. Based on volume and profitability estimated in this manner, the top five countries that have the best combination of high volumes and low production costs are Malaysia, Indonesia, Argentina, the US, and Brazil. Collectively, these countries account for over $80 \%$ of the total biodiesel production. Plant oils currently used in biodiesel production account for only approximately $2 \%$ of global vegetableoil production, with the remainder going primarily to food supplies.

Despite the fact that India has not attained the high level of ethanol production seen in Brazil, it is the largest producer of sugar in the world. Indian ethanol is blended at $5 \%$ with gasoline in nine Indian states and an additional $500 \mathrm{Ml}$ would be needed for full directive implementation. The total demand for ethanol is approximately $4.6 \mathrm{Gl}$ (Subramanian et al., 2005). The country burns 3 times more fossil diesel fuel than gasoline (i.e., roughly $44 \mathrm{Mt}$ ), mainly for transportation purposes.

Because India imports 70\% of its fuel ( 111 Mt), any source of renewable energy is welcome. Therefore, India has established a market for 10\% biodiesel blends (Kumar \& Sharma, 2008). Because India is a net importer of edible oils, it emphasizes non-edible oils from plants such as physic nut, karanja, neem, mahua and simarouba. Physic nut and karanja are the two leaders on the Indian plant list for biodiesel production. 
Of its 306 Mha of land, 173 Mha are already under cultivation. The remainder is classified as either eroded farmland or non-arable wasteland. Nearly 40\% (80-100 Mha) of the land area is degraded because of improper land use and population pressures over a number of years. These wasted areas are considered candidates for restoration with physic nuts (Kumar \& Sharma, 2008). Nearly 80,000 of India's 600,000 villages currently have no access to fuel or electricity, in part because there is not enough fuel to warrant a complete distribution network. Physic nuts could bring oil directly into the villages and allow them to develop their local economies (Fairless, 2007). This also applies to developing areas of Brazil and Africa.

In addition to the biodiesel initiative, regular motorcycles with $100 \mathrm{~cm}^{3}$ internal combustion engines have been converted to run on hydrogen. The efficiency of these motorcycles has been proven to be greater than $50 \mathrm{~km} /$ charge. This development has had great significance because $70 \%$ of privately owned vehicles in India are motorcycles and scooters. Efforts are also underway to adapt light cars and buses to hydrogen, a move that will likely be helped by the growing number of electric and compressed natural gas (CNG) vehicles in and around New Delhi (Solomon \& Banerjee, 2006).

In China, the area of arable land per capita is lower than the world's average. As a result, most edible oils are imported and the demand for edible oils in 2010 is projected to be 13.5 Mt. Because of its large population, China desperately needs sustainable energy sources. Because little arable land is available, China is exploring possibilities for the production of second- and third-generation biofuels (Meng et al., 2008). China is a large developing country that has vast degraded lands and that needs large quantities of renewable energy to meet its rapidly growing economy and accompanying demands for sustainable development. The energy output of biomass grown on degraded soil is nearly equal to that of ethanol from conventional corn grown on fertile soil. Biofuel from biomass is far more economic than conventional biofuels such as corn ethanol or soybean biodiesel. Potential energy production from biomass could reach 6,350,971 terajoules per year (TJ/yr) and an increased value of biomass in China's energy portfolio is considered unavoidable (Zhou et al., 2008).

Taking advantage of seawater availability, biodiesel from microalgae could also be conveniently grown along the 18,000 km Chinese coastline (Song et al., 2008). Marine microalgae production requires unused desert land, seawater, $\mathrm{CO}_{2}$ and sunshine. Given the abundant areas of mudflats and saline lands in China, there is great potential to develop biodiesel production from marine microalgae.

Sales of electric bicycles and scooters in China have grown dramatically in the last 10 years and now total over 1 million per year. The growth of this demand has been facilitated by bans on gasoline-fueled bicycles and scooters in Beijing and Shanghai (among other large cities) because of increasing concerns about pollution (Solomon \& Banerjee, 2006). For this reason, China has become one of the largest potential markets for hydrogen fuel cells in the transportation sector.

Frequent droughts in many Asian countries have made it difficult for them to replicate Brazil's success with sugarcane, which needs an abundant water supply. Thailand and Indonesia are tapping the potential with palm oil.

Because of its need to retain its position as the high-tech superpower for new technologies, Japan has become one of the most important players in the international development of a hydrogen-based economy. Following Japanese estimations, the hydrogen production potential from renewable energy in Japan is $210 \mathrm{GNm}^{3} / \mathrm{yr}\left(\mathrm{Nm}^{3}\right.$ is the gas volume 
in $\mathrm{m}^{3}$ at $0{ }^{\circ} \mathrm{C}$ and one atmosphere), which is 4 times more than what it will actually need in 2030. However, hydrogen based on renewable sources is only expected to contribute approximately $15 \%$ of the hydrogen consumed by 2030. It is estimated that on-board reforming of methanol or gasoline for fuel cell propelling would be the most practical technology in the near term, but the long-term goal is to adopt pure hydrogen (Solomon \& Banerjee, 2006).

\section{Microdiesel}

Oleaginous microorganisms are microbes with an oil content that exceeds $20 \%$. Biodiesel production from microbial lipids (known as single-cell oil or microdiesel) has attracted great attention worldwide. Although microorganisms that store oils are found among various microbes (such as microalgae, bacillus, fungi and yeast), not all microbes are suitable for biodiesel production (Demirbas, 2010).

Most bacteria are generally not good oil producers. Some exceptions are actinomycetes, which are capable of synthesizing remarkably high amounts of fatty acids (up to $\sim 70 \%$ of their dry weight) from simple carbon sources such as glucose under growth-restricted conditions and which accumulate these fatty acids intracellularly as triglycerides (Alvarez \& Steinbuchel, 2002).

The most efficient oleaginous yeast, Cryptococcus curvatus, can accumulate $>60 \%$ lipids when grown under nitrogen-limiting conditions. These lipids are generally stored as triglycerides with approximately $44 \%$ percent saturated fatty acids, which is similar to many plant seed oils. Rhodotorula glutinis has been used for the wastewater treatment in monosodium-glutamate manufacturing. Monosodium-glutamate wastewater is as a cheap fermentation broth for the production of biodiesel using lipids from $R$. glutinis. To be efficient, the fermentation process needs a complementary source of glucose to obtain the proper C:N:P ratio (1:2.4:0.005). This process leads to a lipid production corresponding to $20 \%$ of the biomass after $72 \mathrm{~h}$ of culture and to an oil transesterification rate of $92 \%$ (Xue et al., 2008). In addition, $R$. glutinis can use various carbon sources including dextrose, xylose, glycerol, dextrose and xylose, xylose and glycerol, or dextrose and glycerol and can accumulate 16, 12, 25, 10, 21, and 34\% triglycerides, respectively. The rate of unsaturated fatty acid accumulation was found to depend on the carbon source, with $25 \%$ and $53 \%$ accumulation when $R$. glutinis was grown on xylose and glycerol, respectively (Easterling et al., 2008). These results indicate that the use of $R$. glutinis can add value to several by-products, including glycerol. However, the resulting high levels of unsaturated fatty acids may require some additional saturation step to meet biodiesel standards.

Cyanobacteria are gram-negative photoautotrophic prokaryotes that can be cultivated under aqueous conditions ranging from freshwater to extreme salinity. They are able to produce a wide range of fats, oils, sugars and functional bioactive compounds such that their inclusion to wastewater treatment processes has been proposed (Markou \& Georgakakis, 2011). Their duplication time is $3.5 \mathrm{~h}$ in the log phase of cell multiplication (Chisti, 2007). Using light energy, they are able to convert carbon substrates into oil (with a fatty acid composition that is similar to that of plants) at a rate of $20-40 \%$ of dry biomass (Meng et al., 2008).

Although microalgae are high-lipid-storing microbes, they require larger areas and longer fermentation times than do bacteria. The microalgae market produces approximately 5,000 $\mathrm{t}$ of dry biomass/year and generates approximately US\$ 1.25 bn/yr (Pulz \& Gross, 2004). 
Eukaryotic diatoms, green algae and brown algae isolated from oceans and lakes typically reach dry-mass levels of $20 \%-50 \%$ lipids (Brennan \& Owende, 2010). The quantities of lipids found in microalgae can be extraordinarily high. In Botryococcus, for instance, the concentration of hydrocarbons may exceed $80 \%$ of the dry matter. In comparison, drybiomass plant oil levels are generally around 15-40\% lipids (Spolaore et al., 2006).

There are approximately 300 strains of algae, among which diatoms (including genera Amphora, Cymbella, and Nitzschia) and green algae (particularly genera Chlorella) that are the most suitable for biodiesel production. The oil is accumulated in almost all microalgaes as triglycerides (>80\%) that are rich in C16 and C18 (Meng et al., 2008). Lipid accumulation in oleaginous microorganisms begins with nitrogen exhaust or when carbon is in excess (Ratledge 2002).

Chlorella protothecoides can accumulate lipids at a rate of $55 \%$ by heterotrophic growth under $\mathrm{CO}_{2}$ filtration. Large quantities of microalgal oil have been efficiently recovered from these heterotrophic cells by n-hexane extraction. The microdiesel from heterotrophic microalgal oil obtained by acidic transesterification is comparable to fossil diesel and should be a competitive alternative to conventional biodiesel because of higher photosynthetic efficiency, larger quantities of biomass, and faster growth rates of microalgae as compared to those of plants (Song et al., 2008).

As stated above, microalgal oils differ from most plant oils in being quite rich in polyunsaturated fatty acids with four or more double bonds (Belarbi et al., 2000). This makes them susceptible to oxidation during storage and reduces their suitability for commercial biodiesel (Chisti, 2007). However, fatty acids with more than four double bonds can be easily reduced by partial catalytic hydrogenation (Dijkstra, 2006).

Changes in the degree of fatty acid unsaturation and the decrease or increase of fatty acid length are major challenges in modifying the lipid composition of microalgal oils. These features are regulated by enzymes that are mostly bounded to the cell membrane, which complicates their investigation (Certik \& Shimizu, 1999). Currently, most of the genetic manipulations that have aimed to optimize metabolic pathways have been carried out on oleaginous microorganisms. This is mainly because of their abilities to accumulate high amounts of intracellular lipids, their relatively fast growth rates and their similarities of oil composition with plants (Kalscheuer et al., 2006a, 2006b).

Microalgae are often used for the sequestration and recycling of $\mathrm{CO}_{2}$ by " $\mathrm{CO}_{2}$ filtration" (Haag, 2007) and can reduce $\mathrm{CO}_{2}$ exhaust by $82 \%$ on sunny days and by $50 \%$ on cloudy days (Vunjak-Novakovic et al., 2005). This process is much more elegant than carbon storage (CCS) in depleted oil fields or in aquifers because the carbon can be recycled via microdiesel. The storage capacity of CCS is estimated to range between 2,000-11,000 Gt $\mathrm{CO}_{2}$; however, such aquifers are not evenly distributed around the world (Schiermeier et al., 2008). In addition, CCS does not result in any profit from the $\mathrm{CO}_{2}$ that is stored and is actually an additional cost in the whole process. In contrast, algae convert $\mathrm{CO}_{2}$ into oil. This means that the energy contained in the $\mathrm{CO}_{2}$ can be re-injected into the power plant after being filtered by the algae and transformed into microdiesel.

The stimulation of fish production by increasing phytoplankton biomass through $\mathrm{CO}_{2}$ injection into specific ocean localities has also been proposed (Markels \& Barber, 2001). However, ocean fertilization has been severely challenged because it would eventually destroy the local ecosystem (Bertram, 2010; Glibert et al., 2008). 


\section{Biohydrogen}

The main alternative energy carriers considered for transportation are electricity and hydrogen. With interest in its practical applications dating back almost 200 years, hydrogen energy is hardly a novel idea. Iceland and Brazil are the only nations where renewableenergy feedstocks are envisioned as the major or sole future source of hydrogen (Solomon \& Banerjee, 2006). Fuel-cell vehicles (FCVs) powered by hydrogen are seen by many analysts as an urgent need and as the only viable alternative for the future of transportation (Cropper et al., 2004).

Unlike crude oil or natural gas, reserves of molecular $\mathrm{H}_{2}$ do not exist on earth. Therefore, $\mathrm{H}_{2}$ must be considered more as an energy carrier (like electricity) than as an energy source (Song, 2006). $\mathrm{H}_{2}$ can be derived from existing fuels such as natural gas, methanol or gasoline; however, the best long-term solution is to produce $\mathrm{H}_{2}$ from water by (for example) using heat from solar sources and $\mathrm{O}_{2}$ from the atmosphere.

Today, hydrogen is mainly manufactured by decarbonizing fossil fuels, but in the future it will be possible to produce hydrogen by alternative methods such as water photolysis using semiconductors (Khaselev \& Turner, 1998) or by ocean thermal-energy conversion (Avery, 2002). Such methods are still in the research and development stage and are not yet ready for industrial application.

Hydrogen production from biomass requires multiple reaction steps. The reformation of fuels is followed by two steps in the water-gas shift reaction, a final carbon monoxide purification step and carbon dioxide removal.

Biomass can be thermally processed through gasification or pyrolysis. The main gaseous products resulting from the biomass are expressed by equations (6), (7) and (8) (Kikuchi, 2006).

$$
\begin{gathered}
\text { pyrolysis of biomass } \rightarrow \mathrm{H}_{2}+\mathrm{CO}_{2}+\mathrm{CO}+\text { hydrocarbon gases } \\
\text { catalytic steam reforming of biomass } \rightarrow \mathrm{H}_{2}+\mathrm{CO}_{2}+\mathrm{CO} \\
\text { gasification of biomass } \rightarrow \mathrm{H}_{2}+\mathrm{CO}_{2}+\mathrm{CO}+\mathrm{N}_{2}
\end{gathered}
$$

Hydrogen from organic wastes has generally been produced through equations (9), (10) and (11).

$$
\begin{gathered}
\text { solid waste } \rightarrow \mathrm{CO}+\mathrm{H}_{2} \\
\text { biomass }+\mathrm{H}_{2} \mathrm{O}+\text { Air } \rightarrow \mathrm{H}_{2}+\mathrm{CO}_{2} \\
\text { cellulose }+\mathrm{H}_{2} \mathrm{O}+\text { Air } \rightarrow \mathrm{H}_{2}+\mathrm{CO}+\mathrm{CH}_{4}
\end{gathered}
$$

In the long run, the methods used for hydrogen production are expected to be specific to the locality. They are expected to include steam reforming of methane and electrolysis when hydropower is available (such as in Brazil, Canada and Scandinavia) (Gummer \& Head, 2003). When hydrogen will become a very common energy source, it will likely be distributed through pipelines. Existing systems, such as the regional $\mathrm{H}_{2}$-distribution network that has been operated for more than 50 years in Germany and the intercontinental 
liquid-hydrogen transport chain, demonstrate that leak rates of $<0.1 \%$ can be achieved in industrial applications (Schultz et al., 2003). However, a major threat associated with the hydrogen paradigm is the fact that it is the smallest atom and that leakage is apparently unavoidable. One has to face the possibility that a significant amount of $\mathrm{H}_{2}$ will be released into the stratosphere. Hydrogen is expected to react with ozone following the reaction $\mathrm{H}_{2}+\mathrm{O}_{3} \rightarrow \mathrm{H}_{2} \mathrm{O}+\mathrm{O}_{2}$. This mechanism (reviewed by Kikuchi, 2006) is a potentially dangerous promoter of ozone depletion. Alternatively, hydrogen can be produced from another fuel (e.g., ethanol, biodiesel, gasoline, or synfuel) via onboard reformers (hydrogen fuel processors). This is probably the best solution because synfuel can be produced from local feedstocks through the Fischer-Tropsch process, transported and distributed through existing technologies and infrastructures (Agrawal et al., 2007; Takeshita \& Yamaji, 2008). This consideration also applies to biofuels. In addition, the feasibility of cars with onboard reformers has already been proven. The importance of synfuel is expected to increase rapidly because growing reserves of natural gas (or "stranded" gas) are available in remote locations and are considered to be too small for liquefied natural gas (LNG) or pipeline projects.

The biological generation of hydrogen (or biohydrogen) provides a wide range of approaches for generating hydrogen, including direct biophotolysis, indirect biophotolysis, photo-fermentation and dark-fermentation (Lin et al., 2010). Biological hydrogen production processes are found to be more environmentally friendly and less energy intensive as compared to thermochemical and electrochemical processes. There are three types of microorganisms that produce hydrogen, namely cyanobacteria, anaerobic bacteria, and fermentative bacteria (Demirbas, 2008a).

Photosynthetic production of $\mathrm{H}_{2}$ from water is a biological process that can convert sunlight into useful, stored chemical energy. Hydrogen production is a property of many phototrophic organisms and the list of $\mathrm{H}_{2}$ producers includes several hundred species from different genera of both prokaryotes and eukaryotes. The enzyme-mediating $\mathrm{H}_{2}$ production seen in green algae is effected by a reversible hydrogenase that can catalyze ferredoxin oxidation in the absence of ATP (Beer et al., 2009). The enzyme is sensitive to oxidation; however, tolerant allozymes are being selected (Seibert et al., 2001). Hydrogen production has also been obtained from glucose using NADP+-dependent enzymes, glucose- 6 phosphate dehydrogenase (G6PDH), 6-phosphogluconate dehydrogenase (6PGDH) and hydrogenase (Heyer \& Woodward, 2001).

Carbon monoxide (CO) can be metabolized by a number of naturally occurring microorganisms along with water to produce $\mathrm{H}_{2}$ and $\mathrm{CO}_{2}$ following equation (12), which is the "water-gas shift" reaction, at ambient temperatures.

$$
\mathrm{CO}+\mathrm{H}_{2} \mathrm{O} \leftrightarrow \mathrm{CO}_{2}+\mathrm{H}_{2}
$$

The biological water-gas shift reaction has been used in the processing of syngas from biomass with the bacterium Rubrivivax gelatinosus (Wolfrum \& Watt, 2001).

Nitrogenases can produce hydrogen but require relatively high energy consumption. However, the nitrogenase reaction is essentially irreversible, which allows for hydrogen pressurization. Rhodopseudomonas palustris can drive the nitrogenase reaction using light (Wall, 2004). 


\section{The future of transport technology}

\subsection{Fuel cells}

The fuel cell is the central component of hydrogen cars; it performs the conversion of fuel energy into electricity through proton mobilization. Fuel cells do not have moving parts, they produce only clean water and low-voltage electricity using hydrogen and oxygen, they are not noisy and they are $60 \%$ efficient, which is more than internal combustion engines (ICE, 45\% efficiency). Laboratory tests indicate that fuel cells have a potential efficiency of $85 \%$ or more, which when combined with an $80 \%$-efficient electric motor could make them 2 times more efficient than the direct use of hydrogen in an ICE (Ross, 2006).

Because of the security and cost problems related to infrastructure for hydrogen distribution and storage, ethanol is currently the most convenient alternative for fuel cells. Ethanol can be converted in hydrogen by onboard steam reforming or can be more conveniently used as a proton donor in specific fuel-cell technologies (Lamy et al., 2004). Ethanol-based steam reforming is performed following equation (13) (Velu et al., 2005).

$$
\mathrm{C}_{2} \mathrm{H}_{5} \mathrm{OH}+3 \mathrm{H}_{2} \mathrm{O} \rightarrow 2 \mathrm{CO}_{2}+6 \mathrm{H}_{2}
$$

Deluga et al. (2004) described an onboard system for hydrogen production by auto-thermal reforming from ethanol. Following this system, ethanol and ethanol-water mixtures were converted directly into $\mathrm{H}_{2}$ by catalytic oxidation with $\sim 100 \%$ selectivity and $>95 \%$ conversion and with a residence time on rhodium catalysts of $<10$ milliseconds. This process has great potential for low-cost $\mathrm{H}_{2}$ generation in fuel cells for small portable applications in which liquid-fuel storage is essential and in which systems must be small, simple, and robust.

Another strategy of energy extraction from simple organic molecules is the glycerol biofuel cell (Arechederra et al., 2007). A biofuel cell is similar to a traditional proton exchange membrane (PEM) fuel cell. Rather than using precious metals as catalysts, biofuel cells rely on biological molecules (such as enzymes) to carry out the reactions. Arechederra et al. (2007) were able to immobilize two oxidoreductase enzymes (pyrroloquinoline quininedependent alcohol dehydrogenase and pyrroloquinoline quinine-dependent aldehyde dehydrogenase) at the surface of a carbon anode and to undertake a multi-step oxidation of glycerol into mesoxalic acid with $86 \%$ use of the glycerol energy. The bioanodes resulted in power densities of up to $1.21 \mathrm{~mW} / \mathrm{cm}^{2}$ using glycerol at concentrations up to $99 \%$. Because Nafion (the membrane) does not swell under glycerol, the biofuel cell longevity is expected to be higher than the technology used at moment.

Formula 1 has entered the race for optimizing green technologies. From 2009 on, new regulations for Formula 1 have forced the racing teams to recover the energy lost in braking and to use it to propel the car (Trabesinger, 2007). The technology that accomplishes this is called a "kinetic-energy recovery system" (KERS, better known as "regenerative braking"). In a hybrid car with both combustion and electric motors, batteries can be charged either by the ICE or by regenerative braking. The stored electric energy is then used to power the car at low speeds (i.e., in the city traffic) where the ICE efficiency is low because of continuous "stop-and-go" motion.

Fuel cells are still very expensive and currently cost approximately US\$ 4,000/ $\mathrm{kW}$, which is 100 times more expensive than the cost of ICEs. Fuel-cell stacks must be replaced 4-5 times during the lifetime of current generations of vehicle. It is thus the cost of 4-5 fuel-cell units that must be compared with alternative ICEs (Marcinkoski et al., 2008; Sorensen, 2007). 
Therefore, to be competitive with ICEs, the technology must reach the threshold of US\$ $30 / \mathrm{kW}$. To address this situation, Honda is selling its first prototype fuel-cell car under a leasing contract in California. BMW has been a pioneer of fuel-cell technology and produced its first hydrogen-car prototype in the 1960s (Hissel et al., 2004). Its current vehicle uses liquid hydrogen with autonomy of up to $386 \mathrm{~km}$. The Ford Motor Company has set a new land-speed record for a fuel-cell powered car $(334 \mathrm{~km} / \mathrm{h})$.

Despite these pilot experiments, it is likely that urban buses will be among the first large scale commercial applications for fuel cells. This is due to the fact that urban buses are highly visible to the public, contribute significantly to air and noise pollution in urban areas, have few size limitations and are fueled via a centralized infrastructure. Folkesson et al. (2003) reported the following: (i) the net efficiency of a Scania bus powered by a hybrid PEM fuel-cell system was approximately $40 \%$; (ii) the fuel consumption of the hybrid bus was between 42 and $48 \%$ lower than that of a standard ICE Scania bus; and (iii) regenerative braking saved up to $28 \%$ energy. The bus prototype was equipped with a fuel cell of $50 \mathrm{~kW}$ and was fueled with compressed ambient air and compressed hydrogen stored on the roof. All of the fossil fuel options result in large amounts of GHG emissions. Ethanol and hydrogen have the potential to significantly reduce greenhouse gas emissions. However, their use will be highly dependent on pathways of ethanol and hydrogen production. Some of the hydrogen options result in higher GHG emissions than do ICEs running on gasoline. The vehicle options that will be competitive during the next two decades are those that use improved ICEs (including hybrids burning 'clean' gasoline or diesel). In the present state of the technology, cars running on hydrogen using onboard reforming of carbon fuel are still ecologically less efficient than are gasoline ICEs. The relatively high energy consumption required to produce hydrogen is expected to affect the geographic distribution of hydrogenpowered cars. One can speculate that such cars would be more appropriate in areas where solar (Eugenia Corria et al., 2006), wind or hydro-electricity power sources are abundant.

\subsection{Energy storage}

A variation on the hybrid vehicle is the 'plug-in hybrid', which can be connected to the electric grid. The savings in energy costs over the whole cycle of charging an onboard battery and then discharging it to run an electric motor in an electric-hybrid (e-hybrid) car is $80 \%$. This figure is approximately 4 times higher than the savings from fuel-cell cars running on hydrogen made using electrolysis and 30\% higher than savings from cars running on gasoline (Romm, 2006). These vehicles allow the replacement of a substantial portion of the fuel consumption and tailpipe emissions. If the electricity is produced from $\mathrm{CO}_{2}$-free sources, then e-hybrids can also have dramatically reduced net greenhouse gas emissions.

The electrical storage system is the key element of the e-hybrid car because its power capacity and lifetime decisively define the costs of the overall system (Bitsche \& Gutmann, 2004).

Bio-based energy-management processes are emerging and could make a significant contribution in the medium term. The production of electricity is also possible with wholemicroorganism fermentation. Fe(III)-reducing microorganisms in the family Geobacteraceae can directly transfer electrons onto electrodes (Bond et al., 2002; Bond \& Lovley, 2003). However, the range of electron donors that these organisms can use is limited to simple organic acids. By contrast, Rhodoferax ferrireducens is capable of oxidizing glucose and other sugars (such as fructose and xylose) with similar efficiency and of quantitatively 
transferring electrons to graphite electrodes. The sugar is consumed in the anode chamber. The oxidation of one molecule of glucose produces $\mathrm{CO} 2, \mathrm{H}+$ and 24 electrons with a $\sim 83 \%$ efficiency. The reaction produces a long-term steady current that is sustained after glucosemedium refreshing in the anode chamber. This microbial fuel cell can be recharged by changing the anode medium. It does not show severe capacity fading in the charge/discharge cycling and only presents low-capacity losses under open circuits and prolonged idle conditions (Chaudhuri \& Lovley, 2003).

Another bacterium that is able to transfer electrons to solid metal oxides is Shewanella oneidensis MR-1. In addition, to their remarkable anaerobic versatility, analyses of the genome sequences of Shewanellae species suggest that they can use a broad range of carbon substrates; this creates possibilities for their application in biofuel production (Fredrickson, 2008). Production and storage of electricity are expected to evolve quickly within the new paradigm of emerging bioelectronics (Willner, 2002).

Sol-gels have been demonstrated to be usable for the entrapment of membrane-bound proteins in a physiologically active form and have been proven to be capable of maintaining protein activity over periods of months or more (Luo et al., 2005). Using a membraneassociated $\mathrm{F}_{0} \mathrm{~F}_{1}$-ATP synthase, Luo et al. (2005) showed that the photo-induced proton gradient can be used to 'store' light energy as ATP. This has the advantage of eliminating passive leakage of ions across the membrane. In addition, ATP can be used for direct powering of motor proteins for the conversion of chemical energy to mechanical energy (Browne \& Feringa, 2006). Nano power plants based on the rotation of magnetic bead propellers mounted on $\mathrm{F}_{0} \mathrm{~F}_{1}$-ATP synthase rotors that are fed by ATP to induce electric current in microarrays of nanostators are now being designed and are in the research and development stage of construction (Soong et al., 2000; Yasuda et al., 2001).

\section{Options for grid contributions}

Electricity is the foundation of modern societies, yet more than 1.6 billion people remain without access to the electrical grid. A majority of this population lives in South Asia and sub-Saharan Africa. Despite global economic expansion and advances in energy technologies, roughly 1.4 billion people (or $18 \%$ of the world's population) will still be without power by 2030 unless major governmental incentives are put into place (Dorian et al., 2006).

The world average annual electricity consumption is between 2 and 4 TW. The cost of fossilderived electricity is now in the range of US\$ $0.02-0.05 / \mathrm{kW} / \mathrm{hr}$, including storage and distribution costs (Lewis \& Nocera, 2006). For comparison, the options of non-biological electricity generation are as follows. (i) The light-water reactors that make up most of the world's nuclear capacity produce electricity at costs of US\$ $0.025-0.07 / \mathrm{kW} /$; however, there is no consensus as to the solution to the problem of how to deal with the nuclear wastes that have been generated in nuclear power plants over the past 50 years (Schiermeier et al., 2008). (ii) Hydroelectric energy sources have a generating capacity of $800 \mathrm{GW}$ (i.e., 10 times more power than geothermal, solar and wind power sources combined) and currently supply approximately one-fifth of the electricity consumed worldwide. Annual operating costs are US\$ $0.03-0.10 / \mathrm{kW} / \mathrm{h}$, which makes such sources competitive with coal and gas. Because only approximately $30 \%$ of worldwide hydroelectric capacity is currently used, energy from these sources can still be tripled (Schiermeier et al., 2008). (iii) Wind turbines can produce $1,500 \mathrm{~kW}$ at US\$ $0.05-0.09 / \mathrm{kW} / \mathrm{h}$ making wind competitive with coal; wind 
power could provide up to $20 \%$ of the electricity in the grid. The EU should be able to meet $25 \%$ of its current electricity needs by developing wind power in less than $5 \%$ of the North Sea and is heavily investing in that option. (iv) Exploitation and resulting use of the best geothermal sites is estimated to cost approximately US\$ $0.05 / \mathrm{kW} / \mathrm{h}$. Thus, $70 \mathrm{GW}$ of the global heat flux is seen as exploitable. However, because of the great deal of investment required, exploitation of geothermal power lies outside of current priorities except in regions with significant volcanic activity (Schiermeier et al., 2008). (iv) Commercial photovoltaic (PV) electricity costs US\$ $0.25-0.30 / \mathrm{kW} / \mathrm{h}$, which is still 10 times more than the current price of electricity on the grid.

The possibility for use of current PV technology is limited to $31 \%$ by theoretical considerations. A conversion efficiency of $>31 \%$ is possible if photons with high energies are converted to electricity rather than to heat. With use of such technology, the conversion efficiency could be $>60 \%$ (Lewis, 2007). The absence of a cost-effective storage method for solar electricity is also a major problem. Currently, the cheapest method of solar-energy capture, conversion, and storage is solar thermal technology, which can cost as little as US\$ $0.10-0.15 / \mathrm{kW} / \mathrm{h}$ for electricity production. This requires the focusing of the energy in sunlight for syngas or synfuel synthesis (Lewis \& Nocera, 2006) or its thermal capture by heat-transfer fluids that are able to sustain high temperatures $\left(>427{ }^{\circ} \mathrm{C}\right)$ and resulting electricity generation through steam production (see in Shinnar \& Citro, 2006). Solar power is among the most promising carbon-free technologies available today (Schiermeier et al., 2008). The earth receives approximately $100,000 \mathrm{TW}$ of solar energy each year. There are areas in the Sahara Desert, the Gobi Desert in central Asia, the Atacama in Peru and the Great Basin in the US that are suitable for the conversion of solar energy to electricity. The total world energy needs could be fed using solar energy captured in less than a tenth of the area of the Sahara. Residential and commercial roof surfaces are already being used in several countries to allow the people to sell their own PV electricity to the grid (and in this way saving substantial annual costs). This elegant strategy could be extended to other systems of energy production.

The capital costs of biomass are similar to those of fossil fuel plants. Power costs can be as little as US\$ $0.02 / \mathrm{kW} / \mathrm{h}$ when biomass is burned with coal in a conventional power plant. Costs increase to US\$ $0.04-0.09 / \mathrm{kW} / \mathrm{h}$ for a co-generation plant, but the recovery and use of the waste heat makes the process much more efficient. The biggest problem for new biomass power plants is finding a reliable and concentrated feedstock that is available locally. Biomass production is limited by land-surface availability, the efficiency of photosynthesis, and the water supply. Biomass potential is estimated at $\sim 5$ TW (Schiermeier et al., 2008). Photosynthesis is relatively inefficient if one considers that in switchgrass (one of the fastestgrowing crops), energy is stored in biomass at an average rate of $<1 \mathrm{~W} / \mathrm{m}^{2} / \mathrm{yr}$. Given that the average insolation produces $200-300 \mathrm{~W} / \mathrm{m}^{2}$, the average annual energy conversion and storage efficiency of the fastest growing crops is only $<0.5 \%$ (Lewis 2007; Lewis \& Nocera, 2006). However, photosynthetic efficiency can be improved by genetic engineering (Ragauskas et al., 2006). Another potential problem with biomass production is that it could result in an increase of water consumption of two to three orders of magnitude. This is an important consideration because basic human necessities and power generation are increasingly competing for water resources (King et al., 2008).

The potential availability of wind (Pryor \& Barthelmie, 2010), solar and biomass energy varies over time and location. This variation is not only caused by the individual characteristics of each resource (e.g., wind and solar regimes, soils), but also by geographic 
(land use and land cover), techno-economic (scale and labor costs) and institutional (policy regimes and legislation) factors (de Vries et al., 2007). The regional potential in energy units/year must be integrated over the geographical units that belong to a particular region. The model from de Vries et al. (2007) showed the following: (i) electricity from solar energy is typically available from Northern Africa, South Africa, the Middle East, India, and Australia; (ii) wind is concentrated in temperate zones such as Chile, Scandinavia, Canada, and the USA; (iii) biomass can be produced on vast tracts of abandoned agricultural land typically found in the USA, Europe, the Former Soviet Union (FSU), Brazil, China and on grasslands and savannas in other locations. In many areas of India, China, Central America, South Africa and equatorial Africa, these energy sources are available at costs of below US\$ $0.1 / \mathrm{kW} / \mathrm{h}$ and are found in areas where there is already a large demand for electricity (or there will be such demand in the near future). A combination of electricity from wind, biomass and/or solar sources (Eugenia Corria et al., 2006) may yield economies-of-scale in transport and storage systems. Regions with high ratios of solar-wind-biomass potential to current demand for electricity include Canada (mainly wind), African regions (solar-PV and wind), the FSU (wind and biomass), the Middle East (solar-PV) and Oceania (all sources). In other region (such as Southeast Asia and Japan), the solar-wind-biomass supply is significantly lower than the demand for electricity. Ratios of around one are found in Europe and South Asia. The potentials just described depend on many parameters, and their achievement will depend on future land-use policies (de Vries et al., 2007; Miles \& Kapos, 2008).

\section{Management and sustainability}

Adam Smith's notion that by pursuing his own interest a man "frequently promotes that of society more effectively than when he really intends to promote it" and Karl Marx's picture of a society in which "the free development of each is the condition for the free development of all" are both limited by one obvious constraint. The world is finite. This means that when one group of people pursues its own interests, it damages the interests of others (Vertès et al., 2006). The model of Western economies was established using this logic. The theoretical framework of this philosophy is a mathematical model that is based on energy-conservation equations formulated by von Helmholtz in 1847, in which physical variables were arbitrarily substituted by economic ones. The consequences of this model are as follows: (i) the market is a closed circular flux between production and consumption, without inflows or outflows; (ii) natural resources are located in a domain that is separate from that of the closed market system; (iii) the costs of environmental destruction because of economic activities must be considered as unrelated to the closed market system (or at least they cannot be included in the price-formation processes of that system); (iv) the natural resources that are used by the market system are endless and those that are limited in quantity can be substituted by others that are endless; and (v) biophysical limits to the increase of the market system simply do not exist (Nadeau, 2006). This model is obsolete and is based on hypotheses that have no grounding in scientific bases. Sustainable economic solutions to global warming and environmental destruction are impossible to establish under the logic of this model.

As a consequence, the US alone has reached a level of oil consumption in the transportation sector that approaches $14 \mathrm{Mbl} /$ day and corresponds to a release of 0.53 gigatons of carbon per year $(\mathrm{Gt} \mathrm{C} / \mathrm{yr})$. The current global release of carbon from all fossil fuel usage is estimated to be at $7 \mathrm{Gt} \mathrm{C/yr}$ and is expected to rise to $14 \mathrm{Gt} \mathrm{C/yr}$ by 2050 (Agrawal et al., 
2007). It has been estimated that global energy consumption could reach 30-60 TW by 2050 . With world population expected to reach 8 billion by 2030, the scale-up in energy use that is needed to maintain economic growth is critical. China, with 1.3 billion people and a fastgrowing economy, has overtaken Japan to become the second-largest oil consumer behind the US. The Asian giant is currently the largest producer and consumer of coal (Tollefson, 2008) and has announced the construction of 24-32 new nuclear reactors by 2020 (Dorian et al., 2006). If current trends continue, the world will need to spend an estimated $\$ 16$ trillion over the next three decades to maintain and expand its energy supply. Generation, transmission, and distribution of electricity will absorb almost two-thirds of this investment, whereas capital expenditures in the oil and gas sectors will amount to almost $20 \%$ of global energy investment.

Experts believe that peak of world oil production should not occur before at least 30-40 years from now. To put global oil needs into perspective, demand for oil is projected to rise from nearly $80 \mathrm{Mbl} /$ day today to over $120 \mathrm{Mbl} /$ day by 2030. The OPEC nations are currently operating at near full capacity, which caused oil prices to reach US\$120/bl in August 2008. Clearly, the world must find more efficient ways to manage energy. Some argue that the supplies of oil needed to satisfy the growing world demand will become available because of a combination of price and technology incentives (Rafaj \& Kypreos, 2007). As oil prices continue to rise because of increasing difficulties in reaching remaining oil resources, other energy forms will appear (Herrera, 2006). A transition from oil to renewable energy should occur at some point before the world runs out of oil resources (Dorian et al., 2006). Renewable energy sources, including solar, wind, and geothermal, but excluding biofuels, currently provide only $3 \%$ of world energy demand (Dorian et al., 2006). Solutions that use these energy sources should be increased worldwide and should be connected to the electricity grid.

Renewable biodiesel from palm oil and bioethanol from sugarcane are currently the two leaders of plant bioenergy production per hectare. They are being grown in increasing amounts; however, continuous increases in their production are not sustainable and will not resolve the enormously increasing demands for energy. Palm oil yields $\sim 5,0001 /$ ha. In Brazil, the best bioethanol yields from sugarcane are 7,500 1/ha. Most of the energy needed for growing the sugarcane and converting it to ethanol is gained from burning its wastes (e.g., bagasse). For every unit of fossil energy that is consumed by producing sugarcane ethanol, $\sim 8$ units of energy are recovered (Bourne, 2007). The rates of energy recovery from other biofuel crops are usually less than 5. Biofuel crops from the EU are much less productive than palm oil and sugarcane; therefore, B5 enforcement would require that $\sim 13 \%$ of the EU25 arable land be dedicated to biofuel production. This is hardly sustainable (the present situation is $\sim 5$ times less).

Regarding environmental impact, ethanol from corn (for example) contains costs that stem from the copious amounts of nitrogen fertilizer used and the extensive topsoil erosion associated with cultivation. Every year, pesticides, herbicides and fertilizers run off the corn fields and bleed into groundwater. River contamination promotes eutrophication, algal blooms and 'dead zones'. In addition, ethanol importation by industrialized nations could lead to increased ecological destruction in developing countries as indigenous natural habitats are cleared for energy crops (Gui et al., 2008; Marris, 2006; Thomas 2007).

The general feeling is that first-generation biofuels are already reaching saturation because of the limited availability of arable lands. Brazil has additional lands available for sugarcane and physic nut production, whereas India is promoting physic nut cultivation on its 
extensive wastelands. However, the development of these fuels has already been a success because they have demonstrated that motor technology running on ethanol or biodiesel is feasible and can (at least) be used to power public transport.

Fortunately, second-generation biofuels from biomass offer additional opportunities. The cost of feedstock is lower for lignocellulose as compared to the agricultural crops that now contribute up to $70 \%$ of the total production costs for first-generation bioethanol. Even if they are more expensive now, synfuel from biomass sources (such as poplar, willow, and reed grass) could have higher cost effectiveness in the near future than does fuel from sugar beets, wheat and rapeseed sources (Wesseler, 2007; Styles \& Jones, 2008).

Biomass fuels will be another opportunity for the EU to meet its target of energy production from renewable sources. However, this goal has not been met by 2010 as was initially expected (Fischer et al., 2010; Havlík et al., 2010). The European $\mathrm{CO}_{2}$ emissions-trading system of carbon credits seems to be much more cost effective than its biodiesel program because it allows for the purchase of units of $\mathrm{CO}_{2}$ sequestration in tropical climates that have much higher rates of fixation than do temperate ones (Frondel \& Peters, 2007).

Third-generation biofuels have also entered the race for fuel renewability. In terms of total dry matter, sugarcane typically yields $\sim 75 \mathrm{t}$ biomass per hectare, whereas microalgae are able to produce two times more biomass per hectare (Brennan \& Owende, 2010; Chisti, 2007, 2008). Considering a productivity of $150 \mathrm{t} / \mathrm{ha}$ and an average dry-weight oil content of $30 \%$, the oil yield per hectare would be $\sim 123 \mathrm{~m}^{3}$ over $90 \%$ of the year (i.e., $98.4 \mathrm{~m}^{3} / \mathrm{ha}$ ). If $0.53 \mathrm{Gm}^{3}$ of biodiesel are needed in the US to power transport vehicles, microalgae should be grown over an area of $\sim 5.4$ Mha ( $3 \%$ of the US). Producing algal biomass in a $100 \mathrm{t} / \mathrm{yr}$ facility has been estimated to cost approximately US\$ 3,000/ton. The feasibility of oil extraction for microalgal biomass has been demonstrated (Belarbi et al., 2000; Sánchez Mirón et al., 2003) and the majority of algal biomass residues from oil extraction can be recycled by anaerobic digestion to produce biogas.

Impediments to large-scale culture of microalgae are mainly economic and are tied to the investment requirements for the algae cultivation. One solution would be to increase the oil productivity by genetic and metabolic engineering (León-Bañares et al., 2004; Mathews \& Wang, 2009). One may expect the expansion of algal technology via $\mathrm{CO}_{2}$ filtration because power plants can incorporate this technology immediately into their management systems. This technology is expected to spread slowly with the accumulation of experience.

Nearly half of the world's oil consumption is dedicated to the transportation sector, which also accounts for $32 \%$ of GHG emissions. The overall efficiency of energy conversion to work in the transportation segment is lower than it is in large-scale power plants and the goal is to increase it from the current level of 15-35 to 60-80\% (Song, 2006).

Unfortunately, advanced transportation technologies (such as hydrogen fuel cell vehicles and alternative fuels including gas-to-liquids, coal-to-liquids, and biodiesels) are not likely to significantly penetrate the conventional transportation fuel market before 2030 (except on a regional basis). The growth in oil consumption for transportation use in the coming decades may be slowed by the adoption of fourth-generation technologies such as hybrids and fuel cell cars. However, the necessary technological breakthroughs will not occur without unprecedented policy actions worldwide to promote the use and inclusion of these technologies in everyday life (Doniger et al., 2006; Haug et al., 2011; Michel 2009). Currently, there are approximately half a million hybrids and 30 million advanced clean-diesel engines globally. The use of hybrid cars is growing in the US and Japan, whereas advanced cleandiesel motors are mostly concentrated in Europe (Dorian et al., 2006). 
Actually, auto-mobility is a self-organizing and non-linear system that presupposes and calls into existence an assemblage of cars, drivers, roads, fuel supplies, and other objects and technologies. Modern social life has become interconnected with auto-mobility. However, this mode of mobility is neither socially necessary nor inevitable (Urry, 2008). One billion cars were produced during the last century. World automobile travel is predicted to triple between 1990 and 2050 (Hawken et al., 2002). Today, world citizens move $23 \mathrm{Gkm}$ annually. Auto-mobility forces people to contend with the temporal and spatial constraints that it itself generates (Mills et al., 2010). Fortunately, some 35-year-old projects have begun to be finally implemented (i.e., the integration of car and bicycle rentals into public transportation systems, such as occurs in some European cities). A post-car future will involve changes in lifestyles, city architecture, thinking and social practices. Increased active transport (e.g., walking and bicycling) will help to achieve substantial reductions in emissions while improving public health. Cities require safe and pleasant environments for active transport as well as easy accessibility of public transport. Adverse health effects because of transportation include traffic injuries, physical inactivity (the cost of obesity in the USA is estimated to be around US\$ $139 \mathrm{bn} / \mathrm{yr}$ ), urban air pollution, energy-related conflicts, and environmental degradation. For instance, urban air pollution accounts for 750,000 deaths each year, of which 530,000 are in Asia (Woodcock et al., 2007). Because of limited energy resources, it has been argued that the world will be required to move toward virtual travel (such as internet surfing, virtual sensorial traveling, and video conferences) to replace physical travel as much as possible (Moriarty \& Honnery, 2007).

In reality, the situation outlined above is the result of consideration of humanity only within social contexts and without the necessary environmental perspective (Thomas, 2007). The concept of environmental crime barely operational; if it exists at all, it is very recent and is not generally applied. Logical human societies should take into account the amount of land that human beings and wildlife actually need to reasonably sustain themselves. Not doing this will lead to increasing worldwide destruction (Urry, 2008) and will threaten the future of humanity. These considerations led to the formulation of the Gaia principle (Lovelock \& Margulis, 1974). This principle states that one should consider the planet Earth as a whole, with the consequence that the destruction of one ecosystem can affect all of the others. Concern for the value of ecosystems is recent (Costanza et al., 1997). Society has only begun to address human integration with the environment because of the threat of global warming and its potentially disastrous effects (Stern, 2006). A discussion of the economic accounting for ecosystem services from the perspective of sustainable development has also been proposed (Mäler et al., 2008).

The concept of "willingness-to-pay" (WTP) has also been recently introduced. This concept allows for the monetary measurement of individual preference to avoid a negative impact. It aims to estimate the need for improved environmental quality. WTP measures how much individuals are ready to pay to improve their quality of life or that of other people. The sum of the WTP of all individuals gives the value that a group of individuals are ready to pay to maintain their environment in an unaffected state. For example, the pathways of polluting substances are followed from their release sources to the points of damage occurrence with associated "external" costs of reparation. Taking external costs into account in the full cost of energy production leads to the estimation of the "real" cost of an activity and supplies an efficient policy instrument for reducing the negative impacts of energy use (Nast et al., 2007). The approach of merging production costs with external costs into a total specific cost serves as a comparative indicator for the evaluation of the economic-environmental 
performance of energy options and technologies (Rafaj \& Kypreos, 2007). The scenarios proposed under this new cost-accounting strategy reveal the possibilities for the diffusion of advanced technologies and fuel switching into the electricity production system. Following this model, renewable energies increase their competitiveness and the dependency of the electricity sector on fossil fuels is decreased considerably. Additionally, emissions of $\mathrm{SO}_{2}$ and $\mathrm{NO}_{x}$ decrease by $70-85 \%$ by 2030 . Although the analysis indicates that advanced technologies with emission controls and carbon sequestration will undergo significant cost reduction and will become competitive in the long run, policies supporting these technologies are a prerequisite to their establishment in electricity markets (especially during their initial period of market penetration). This model refers to policy measures for the stimulation of technological progress via investments in research and development that assist carbon-free technologies to progress along their necessary learning curves (Haug et al., 2011; Rafaj \& Kypreos, 2007).

\section{Conclusions}

The time has come for the integration of the technological and social sciences to find a route to environmental and economic sustainability on earth. If such a solution is not reached, economic growth will occur at the cost of the human population size (Urry, 2008). Fortunately, because of the continuous increase in the price of fossil fuel, investigations into sources of renewable energy have become economically viable. It is now clear that technologies for renewable energies have reached a pivotal stage such that there is no turning back. There are at least 5 regional blocks (the USA, the EU, China, Brazil, and India) that are interested in decreasing their dependence on fossil fuels. It does not appear to be in anyone's interest to shut this process down by mean of aggressive oil price cutting and market dumping. In fact, biotechnology is intimately bound to agricultural processes that are also supported by governments because of geostrategic issues. In addition, climate change is becoming obvious and will soon overcome particular interests to become a general concern of humanity.

Biofuels and sources of bioenergy will pass through a rapid succession of technological improvements and developments before they arrive in their final forms. It is expected that bioethanol from sweet crops will be surpassed by bioethanol from biomass. Synfuel from biomass and solar energy should also progressively replace plant biodiesel. Biotechnology is expected to increase its participation in microdiesel fuel production, in genetic engineering of plants and microorganisms and in the contribution of enzymes to nanotechnology.

The integration of renewable energies into the electricity grid is just beginning, but is already progressing rapidly. It is expected to make a significant contribution; however, it should be accompanied by policies of energy management and urbanization to avoid unnecessary energy waste that could negate the benefits of technological breakthroughs and developments. New concepts (such as willingness-to-pay, carbon credits and external costs) are now being taken into account in the calculation of energy life cycles. This toolbox will expand with increasing government regulations and should include fundamental concepts such as "biodiversity credits" and the definition of a "minimal territorial unit" for living entities to warrant sustainability of wildlife and humanity. Biodiversity is a source of nanostructures and nanomachines. It should not be destroyed without consideration when we are aware that it required three billions years to develop and that humanity is just beginning to investigate it. 
As a result of energy saving requirements, the cars of the near future will run on combinations of fuel combustion and electricity. Such options can reduce fossil fuel consumption and greenhouse gas emissions by 30 to $50 \%$, with no gross vehicle modifications required. In addition, they will allow for connection to the electricity grid for additional cost saving on electricity consumption. These so-called plug-in hybrids will likely travel three to four times farther per $\mathrm{kW} / \mathrm{h}$ than other vehicles. Ideally, these advanced hybrids will also be flexible and capable of running on bio/fossil blends and gas (Romm, 2006).

At some point during the first half of this century, a transition from fossil fuels to a noncarbon-based world economy will begin and will seriously affect the type of society experienced by future generations (Dorian et al., 2006).

\section{Acknowledgement}

We thank the Coordenação de Aperfeiçoamento de Pessoal de Nível Superior (CAPES) and Fundação Oswaldo Cruz (FIOCRUZ) for providing a research fellowship from the Centro de Desenvolvimento Tecnológico em Saúde (CDTS) to N. Carels. This work received financial support from Conselho Nacional de Desenvolvimento Científico e Tecnológico (CNPq), Brazil (no. 471214/2006-0).

\section{References}

Abollé, A., Kouakou, L. \& Planche, H. 2008. The viscosity of diesel oil and mixtures with straight vegetable oils: Palm, cabbage palm, cotton, groundnut, copra and sunflower. Biomass Bioenergy 33:1116-1121.

Adamson, K.A. 2004. Hydrogen from renewable resources - the hundred year commitment. Energ. Policy 32:1142-1231.

Agarwal, A.K. 2007. Biofuels (alcohols and biodiesel) applications as fuels for internal combustion engines. Prog. Energ. Combust. Sci. 33: 233-271.

Agrawal, R., Singh, N.R., Ribeiro, F.H. \& Delgass, W.N. 2007. Sustainable fuel for the transportation sector. Proc. Natl. Acad. Sci. USA 104:4828-4833.

Agrawal, A., Chhatre, A. \& Hardin, R. 2008. Changing Governance of the World's Forests. Science 320:1460-1462.

Ajanovic, A. 2011. Biofuels versus food production: Does biofuels production increase food prices? Energy, doi:10.1016/j.energy.2010.05.019

Alvarez, H.M. \& Steinbuchel, A. 2002. Triacylglycerols in prokaryotic microorganisms. Appl. Microbiol. Biot. 60:367-376.

Arechederra, R.L., Treu, B.L. \& Minteer, S.D. 2007. Development of glycerol/ $\mathrm{O}_{2}$ biofuel cell. J. Power Sources 173:156-161.

Arthur, R., Baidoo, M.F. \& Antwi, E. 2011. Biogas as a potential renewable energy source: A Ghanaian case study. Renew. Energ. 36:1510-1516.

Asam, Z.-u.-Z. 2011. How can we improve biomethane production per unit of feedstock in biogas plants? Appl. Energ., doi:10.1016/j.apenergy.2010.12.036

Avery, W. 2002. Ocean-thermal energy conversion. In: Encyclopedia of Physical Science and Technology, edited by Meyers, R.A., 123- 160. San Diego: 3rd ed. Academic Press.

Baker, E. \& Keisler, J.M. 2011. Cellulosic biofuels: Expert views on prospects for advancement. Energy 36:595-605. 
Barnet, A. 2008. Europe's 2020 vision. Nat. Rep. Clim. Change 2:36.

Barros, G.S.A.C., Silva, A.P., Ponchio, L.A., Alves, L.A., Osaki, M. \& Cenamo, M. 2006. Custos de produção de biodiesel no Brasil. Revista de Política Agrícola 3:36-50.

Beer, L.L., Boyd, E.S., Peters, J.W. \& Posewitz, M.C. 2009. Engineering algae for biohydrogen and biofuel production. Curr. Opin. Biotech. 20:264-271.

Begum, Z.N. 2005. Modeling of chemical tracer transport in the atmospheric environment and its impact on the global climate. J. Quant. Spectrosc. Radiat. Transfer 95:423-427.

Belarbi, E.-H., Molina Grima, E. \& Chisti, Y. 2000. A process for high yield and scaleable recovery of high purity eicosapentaenoic acid esters from microalgae and fish oil. Enzyme Microb. Tech. 26:516-529.

Bertram, C. 2010. Ocean iron fertilization in the context of the Kyoto protocol and the postKyoto process. Energ. Policy 38:1130-1139

Bindraban, P.S., Bulte, E.H. \& Conijn, S.G. 2009. Can large-scale biofuels production be sustainable by 2020? Agr. Syst. 101:197-199

Bitsche, O. \& Gutmann, G. 2004. Systems for hybrid cars. J. Power Sources 127:8-15.

Bond, D.R., Holmes, D.E., Tender, L.M. \& Lovley, D.R. 2002. Electrode-reducing microorganisms that harvest energy from marine sediments. Science 295:483-485.

Bond, D.R. \& Loveley, D.R. 2003. Electricity production by Geobacter sulfurreducens attached to electrodes. Appl. Environ. Microb. 69:1548-1555.

Bourne, J.K.Jr. 2007 Biofuels: green dreams. National Geographic Magazine (October), 41-59.

Brennan, L. \& Owende, P. 2010. Biofuels from microalgae - A review of technologies for production, processing, and extractions of biofuels and co-products. Renew. Sustain. Energ. Rev. 14:557-577

Browne, W.R. \& Feringa, B.L. 2006. Making molecular machines work. Nature Nanotechnology 1:25-35.

Canakci, M., Erdil, A. \& Arcaklioglu, E. 2006. Performance and exhaust emissions of a biodiesel engine. Appl. Energ. 83, 594-605.

Certik, M. \& Shimizu, S. 1999. Biosynthesis in microorganisms being used for single cell oil production. Biochimie 87:1-14.

Ceschia, E. et al. 2010. Management effects on net ecosystem carbon and GHG budgets at European crop sites. Agricult. Ecosys. Environ. 139:363-383.

Chapple, C., Ladisch, M. \& Meilan, R. 2007. Loosening lignin's grip on biofuel production. Nat. Biotechnol. 25:746-748.

Chaudhuri, S.K. \& Lovley, D.R. 2003. Electricity generation by direct oxidation of glucose in mediatorless microbial fuel cells. Nat. Biotechnol. 21:1229-1232.

Chen, F. \& Dixon, R.A. 2007. Lignin modification improves fermentable sugar yields for biofuel production. Nat. Biotechnol. 25:759-761.

Cherubini, F. 2010. GHG balances of bioenergy systems - Overview of key steps in the production chain and methodological concerns. Renew. Energ. 35:1565-1573.

Chisti, Y. 2007. Biodiesel from microalgae. Biotechnol. Adv. 25:294-306.

Coleman, H.D., Park, J.-Y., Nair, R., Chapple, C. \& Mansfield, S.D. 2008. RNAi-mediated suppression of p-coumaroyl-CoA 3 '-hydroxylase in hybrid poplar impacts lignin deposition and soluble secondary metabolism. Proc. Natl. Acad. Sci. USA 105:45014506.

Costanza, R. et al. 1997. The value of the world's ecosystem services and natural capital. Nature 387, 253-260. 
Cropper, M., Geiger, S. \& Jollie, D. 2004. Fuel cells: a survey of current developments. J. Power Sources 131:57-61.

Damartzis, T. \& Zabaniotou, A. 2011. Thermochemical conversion of biomass to second generation biofuels through integrated process design-A review. Renew. Sustain. Energ. Rev. 15:366-378.

Darussalam, B. 2007. Last-Gasp effort to save Borneo's tropical rainforests. Science 317:192.

Deluga, G.A., Salge, J.R., Schmidt, L.D. \& Verykios, X.E. 2004. Renewable hydrogen from ethanol by autothermal reforming. Science 13:993-997.

Demirbas, M.F. \& Balat, M. 2006. Recent advances on the production and utilization trends of bio-fuels: A global perspective. Energ. Convers. Manage. 47:2371-2381.

Demirbas, A. 2007. The influence of temperature on the yields of compounds existing in biooils obtaining from biomass samples via pyrolysis. Fuel process. Technol. 88:591-597.

Demirbas, A. 2008a. Biofuels sources, biofuel policy, biofuel economy and global biofuel projections. Energ. Convers. Manage. 49:2106-2116.

Demirbas, A. 2008b. Comparison of transesterification methods for production of biodiesel from vegetable oils and fats. Energ. Convers. Manage. 49:125-130.

Demirbas A. 2010. Use of algae as biofuel sources. Energ. Convers. Manage. 51:2738-2749.

de Vries, B.J.M., van Vuuren, D.P. \& Hoogwijk, M.M. 2007. Renewable energy sources: Their global potential for the first-half of the 21st century at a global level: An integrated approach. Energ. Policy 35:2590-2610.

Dijkstra, A.J. 2006. Revisiting the formation of trans isomers during partial hydrogenation of triacylglycerol oils. Eur. J. Lipid Sci. Tech. 108:249-264.

Doniger, D.D., Herzog, A.V. \& Lashof, D.A. 2006. An ambitious, centrist approach to global warming legislation. Science 314:764-765.

Donner, S.D. \& Kucharik, C.J. 2008. Corn-based ethanol production compromises goal of reducing nitrogen export by the Mississippi River. Proc. Natl. Acad. Sci. USA 105:4513-4518.

Dorian, J.P., Franssen, H.T. \& Simbeck, D.R. 2006. Global challenges in energy. Energ. Policy 34:1984-1991.

Easterling, E.R., French, W.T., Hernandez, R. \& Licha, M. 2008. The effect of glycerol as a sole and secondary substrate on the growth and fatty acid composition of Rhodotorula glutinis. Bioresource Technol. 100:356-61

Eugenia Corria, M., Melian Cobas, V. \& Silva Lora, E. 2006. Perspectives of Stirling engines use for distributed generation in Brazil. Energ. Policy 34:3402-3408.

Fagernäs, L., Brammer, J., Wilén, C., Lauer, M.\& Verhoeff, F. 2010 Drying of biomass for second generation synfuel production. Biomass Bioenergy 34:1267-1277.

Fairless, D. 2007. The little shrub that could - maybe. Nature 449:652-655.

Fargione, J., Hill, J., Tilman, D., Polasky, S. \& Hawthorne, P. 2008. Land clearing and the biofuel carbon debt. Science 319:1235-1238.

Fenning, T.M., Walter, C. \& Gartland, K.M.A. 2008. Forest biotech and climate change. Nat. Biotechnol. 26:615-616.

Fialkov, A.B., Gordin, A. \& Amirav, A. 2008. Hydrocarbons and fuels analyses with the supersonic gas chromatography mass spectrometry - The novel concept of isomer abundance analysis. J. Chromatogr. A 1195:127-135.

Fischer, C.R., Klein-Marcuschamer, D. \& Stephanopoulos, G. 2008. Selection and optimization of microbial hosts for biofuel production. Metab. Eng. 10:295-304. 
Fischer, G., Prieler, S., van Velthuizen, H., Lensink, S.M., Londo, M. \& de Wit, M. 2010. Biofuel production potentials in Europe: Sustainable use of cultivated land and pastures. Part I: Land productivity potentials. Biomass Bioenergy 34:159 - 172.

Flavin, C. 2006. American Energy: The Renewable Path to Energy Security. 40 p. Washington DC: Worldwatch Institute.

Folkesson, A., Andersson, C., Alvfors, P., Alaküla, M. \& Overgaard, L. 2003. Real life testing of a Hybrid PEM Fuel Cell Bus. J. Power Sources 118:349-357.

Fredrickson, J.K. et al. 2008. Towards environmental systems biology of Shewanella. Nat. Rev. Microbiol. 6:592-603.

Frondel, M. \& Peters, J. 2007. Biodiesel: a new Oildorado? Energ. Policy 35:1675-84.

García-Montero, L.G., López, E., Monzón, A. \& Pastor, I.O. 2010. Environmental screening tools for assessment of infrastructure plans based on biodiversity preservation and global warming (PEIT, Spain). Environ. Impact Assess. Rev. 30:58-168.

Gavrilescu, M. \& Chisti, Y. 2005. Biotechnology - a sustainable alternative for chemical industry. Biotechnol. Adv. 23:471-499.

Gielen, D.J., Fujino, J., Hashimoto, S. \& Moriguchi, Y. 2002. Biomass strategies for climate policies? Climate Policy 2:319-333.

Glibert, P.M. et al. 2008. Ocean urea fertilization for carbon credits poses high ecological risks. Mar. Pollut. Bull. 56:1049-1056.

Gnansounou, E., Dauriat, A., Villegas, J. \& Panichelli, L. 2009. Life cycle assessment of biofuels: Energy and greenhouse gas balances. Bioresource Technol. 100:4919-4930.

Goering, E., Schwab, W., Daugherty, J., Pryde, H. \& Heakin, J. 1982. Fuel properties of eleven vegetable oils. Transactions ASABE 25:1472-1483.

Goldemberg, J., Coelho, S.T. \& Lucon, O. 2004. How adequate policies can push renewables. Energ. Policy 32:1141-1146.

Gressel, J. 2008. Transgenics are imperative for biofuel crops. Plant Sci. 174:246-263.

Greyvenstein, R., Correia, M. \& Kriel, W. 2008. South Africa's opportunity to maximise the role of nuclear power in a global hydrogen economy. Nucl. Eng. Des. 238:3031-3040.

Gui, M.M., Lee, K.T. \& Bhatia, S. 2008. Feasibility of edible oil vs. non-edible oil vs. waste edible oil as biodiesel feedstock. Energy 33:1646-1653.

Gummer, J.H. \& Head, C.R. 2003. Hydrogen, hydropower and world poverty. Int. J. Hydropower Dams 5:67-71.

Haag, A.L. 2007. Algae bloom again. Nature 447:520-521.

Hagerman, S., Dowlatabadi, H., Satterfield, T. \& McDaniels, T. 2010. Expert views on biodiversity conservation in an era of climate change. Global Environ. Change 20:192-207.

Hall, J., Matos, S., Severino, L. \& Beltrão, N. 2009. Brazilian biofuels and social exclusion: established and concentrated ethanol versus emerging and dispersed biodiesel. J. Clean. Prod. 17:S77-S85.

Haug, C., Huitema, D. \& Wenzler, I. 2011. Learning through games? Evaluating the learning effect of a policy exercise on European climate policy. Technol. Forecast. Soc. Change, doi:10.1016/j.techfore.2010.12.001

Havlík, P. et al. 2010. Global land-use implications of first and second generation biofuel targets. Energ. Policy, doi:10.1016/j.enpol.2010.03.030 
Hawken, P., Lovins, A. \& Lovins, L.H. 2002. Natural Capitalism: Creating the Next Industrial Revolution. London: Earthscan. Accessed February 2, 2010. http://www.natcap.org/.

Herrera, S. 2006. Bonkers about biofuels. Nat. Biotechnol. 24:755-760.

Heyer, N.I. \& Woodward, J. 2001. Efficient hydrogen production using enzymes of the pentose phosphate cycle. Proceedings of the 2001 DOE Hydrogen Program Review, NREL/CP-570-30535. Accessed February 2, 2010. http://www1.eere.energy.gov/hydrogenandfuelcells/pdfs/30535g.pdf.

Hill, J., Nelson, E., Tilman, D., Polasky, S. \& Tiffany D. 2006. Environmental, economic, and energetic costs and benefits of biodiesel and ethanol biofuels. Proc. Natl. Acad. Sci. USA 103:11206-11210.

Himmel, M.E., Ding, S.-Y., Johnson, D.K., Adney, W.S., Nimlos, M.R., Brady, J.W. \& Foust, T.D. 2007. Biomass Recalcitrance: Engineering Plants and Enzymes for Biofuels Production. Science 315:804-807.

Hissel, D., Péra, M.C. \& Kauffmann, J.M. 2004. Diagnosis of automotive fuel cell power generators. J. Power Sources 128:239-246.

Hopkin, M. 2007. Climate sceptics switch focus to economics. Nature 445:582-583.

Howden, S.M., Soussana, J.-F., Tubiello, F.N., Chhetri, N., Dunlop, M. \& Meinke, H. 2007. Adapting agriculture to climate change. Proc. Natl. Acad. Sci. USA 104:19691-19696.

Huston, M.A. \& Marland, G. 2003. Carbon management and biodiversity. J. Environ. Manage. 67:77-86.

Johnston, M. \& Holloway, T. 2007. A global comparison of national biodiesel production potentials. Environ. Sci. Technol 41:7967-7973.

Johnston, C.D., Bastow, T.P. \& Innes, N.L. 2007. The use of biodegradation signatures and biomarkers to differentiate spills of petroleum hydrocarbon liquids in the subsurface and estimate natural mass loss. Eur. J. Soil Biol. 43:328-334.

Jones, D.B. 2010. Proposal for an international carbon fee. Energy for Sustainable Development 14:245-250.

Kalscheuer, R., Stoveken, T. \& Steinbuchel, A. 2006a. Microdiesel: Escherichia coli engineered for fuel production. Microbiology 152:2529-2536.

Kalscheuer, R., Stoveken, T., Luftmann, H., Malkus, U., Reichelt, R. \& Steinbuchel, A. 2006b. Neutral lipid biosynthesis in engineered Escherichia coli: Jojoba oil-like wax esters and fatty acid butyl esters. Appl. Environ. Microbiol. 72:1373-1379.

Kaplan, I.R., Galperin, Y., Lu, S.-T. \& Lee, R.-P. 1997. Forensic environmental geochemistry: differenciation of fuel-types, their sources and release time. Org. Geochem. 27:289317.

Khaselev, O. \& Turner, J. 1998. A monolithic photovolatic-photochemical device for hydrogen production via water splitting. Science 280, 425-427.

Kikuchi, R. 2006. Penetration of hydrogen-based energy system and its potential for causing global environmental change: Scoping risk analysis based on life cycle thinking. Environ. Impact Asses. Rev. 26:206-218.

Kindermann, G., Obersteiner, M., Sohngen, B., Sathaye, J., Andrasko, K., Rametsteiner, E., Schlamadinger, B., Wunder, S. \& Beach, R. 2008. Global cost estimates of reducing carbon emissions through avoided deforestation. Proc. Natl. Acad. Sci. USA 105:10302-10307.

King, C.W., Holman, A.S. \& Webber, M.E. 2008. Thirst for energy. Nat. Geosci. 1:283-286. 
Kirilenko, A.P. \& Sedjo, R.A. 2007. Climate change impacts on forestry. Proc. Natl. Acad. Sci. USA 104:19697-19702.

Kleiner, K. 2007. Civil aviation faces green challenge. Nature 448:120-121.

Kleiner, K. 2008. The backlash against biofuels. Nat. Rep. Clim. Change 2:9-11, doi:10.1038/climate.2007.71.

Kremer, F.G. \& Fachetti, A. 2000 Alcohol as automotive fuel-Brazilian experience. SAE Technical Paper No. 2000-01-1965, doi:10.4271/2000-01-1965

Kumar, A. \& Sharma, S. 2008. An evaluation of multipurpose oil seed crop for industrial uses (Jatropha curcas L.): A review. Ind. Crop. Prod. 28:1-10.

Lamy, C., Rousseau, S., Belgsir, E.M., Coutanceau, C. \& Léger, JM. 2004. Recent progress in the direct ethanol fuel cell: development of new platinum-tin electrocatalysts. Electrochim. Acta 49:3901-3908.

Laurance, W.F. 2007. Switch to corn promotes amazon deforestation. Science 318:1721.

Leibold, H., Hornung, A. \& Seifert, H. 2008. HTHP syngas cleaning concept of two stage biomass gasification for FT synthesis. Powder Technol. 180:265-270.

León-Bañares, R., González-Ballester, D., Galván, A. \& Fernández, E. 2004. Transgenic microalgae as green cellfactories. Trends Biotechnol. 22:45-52.

Lewis, N.S. \& Nocera, D.G. 2006. Powering the planet: Chemical challenges in solar energy utilization. Proc. Natl. Acad. Sci. USA 103:15729-15735.

Lewis, N.S. 2007. Toward cost-effective solar energy use. Science 315:798-801.

Lima, D.G. et al. 2004. Diesel-like fuel obtained by pyrolysis of vegetable oils. J. Anal. Appl. Pyrol. 71:987-996.

Lin, C.-Y. et al. 2010. A pilot-scale high-rate biohydrogen production system with mixed microflora. Int. J. Hydrogen Energ., doi:10.1016/j.ijhydene.2010.07.115.

Liu, X., Li, X., Suehiro, Y. \& Fujimoto, K. (2007). Elucidation of reaction network and effective control of carbon number distribution in the three phase Fischer-Tropsch synthesis. Appl. Catal. A-Gen. 333:211-218.

Lois, E. 2007. Definition of biodiesel. Fuel 86:1212-1213.

Lokey, E. 2007. How the next US president should slow global warming. Energ. Policy 35:5399-5402.

Lonngren, K.E. \& Bai, E.-W. 2008. On the global warming problem due to carbon dioxide. Energ. Policy 36:1567-1568.

Lovelock, J.E. \& Margulis, L. 1974. Atmospheric homeostasis by and for the biosphere- The Gaia hypothesis. Tellus 26:2-10.

Lü, X-c, L., Yang, J-g, Zhang, W-g, Z. \& Huang, Z. 2004. Effect of cetane number improver on heat release rate and emissions of high speed diesel engine fueled with ethanoldiesel blend fuel. Fuel 83:2013-2020.

Luo, T.-J.M., Soong, R., Lan, E., Dunn, B. \& Montemagno, C. 2005. Photo-induced proton gradients and ATP biosynthesis produced by vesicles encapsulated in a silica matrix. Nat. Materials 4:220-224.

Malça, J. \& Freire, F. 2011. Life-cycle studies of biodiesel in Europe: A review addressing the variability of results and modeling issues. Renew. Sustain. Energ. Rev. 15:338-351.

Mäler, K.-G., Aniyar, S. \& Jansson, A.. 2008. Accounting for ecosystem services as a way to understand the requirements for sustainable development. Proc. Natl. Acad. Sci. USA 105:9501-9506. 
Malhi, Y., Roberts, J.T., Betts, R.A., Killeen, T.J., Li, W. \& Nobre, C.A. 2008. Climate change, deforestation, and the fate of the Amazon. Science 319:169-172.

Mander, U. et al. 2010. Assessment of methane and nitrous oxide fluxes in rural landscapes. Landscape Urban Plan. 98:172-181.

Marchetti, J., Miguel, V. \& Errazu, A. 2007. Possible methods for biodiesel production. Renew. Sustain. Energ. Rev. 11:1300-1311.

Marcinkoski, J., Kopasz, J.P. \& Benjamin, T.G. 2008. Progress in the US DOE fuel cell subprogram efforts in polymer electrolyte fuel cells. Int. J. Hydrogen Energ. 33:38943902.

Markels, M. \& Barber, R.T. 2001. Sequestration of carbon dioxide by ocean fertilization. Preprints - American Chemical Society, Division of Petroleum Chemistry 46:45-48.

Markou, G. \& Georgakakis, D. 2011. Cultivation of filamentous cyanobacteria (blue-green algae) in agro-industrial wastes and wastewaters: A review. Appl. Energ., doi:10.1016/j.apenergy.2010.12.042

Marris, E. 2006. Drink the best and drive the rest. Nature 444:670-672.

Mathews, J. \& Wang, G. 2009. Metabolic pathway engineering for enhanced biohydrogen production. Int. J. Hydrogen Energ. 34:7404 - 7416.

Meng, X., Yang, J., Xu, X., Zhang, L., Nie, Q. \& Xian, M. 2008. Biodiesel production from oleaginous microorganisms. Renew. Energ. 34:1-5

Michel, D. 2009. Foxes, hedgehogs, and greenhouse governance: Knowledge, uncertainty, and international policy-making in a warming World. Appl. Energ. 86:258-264.

Miles, L. \& Kapos, V. 2008. Reducing greenhouse gas emissions from deforestation and forest degradation: global land-use implications. Science 320:1454-1455.

Mills, G. et al. 2010. climate information for improved planning and management of mega cities (needs perspective). Procedia Environmental Sciences 1:228-246

Moreira, J.R. \& Goldemberg, J. 1999. The alcohol program. Energ. Policy 27:229-245.

Moriarty, P. \& Honnery, D. 2007. The prospects for global green car mobility. J. Clean. Prod. 16:1717-1726.

Nadeau, R. 2006. The Environment Endgame: Mainstream Economics, Ecological Disaster, and Human Survival. 214 p. London: Rutgers University Press.

Nass, L.L., Pereira, P.A.A. \& Ellis, D. 2007. Biofuels in Brazil: An Overview. Crop Sci. 47:2228-2237.

Nast, M., Langniss, O. \& Leprich, U. 2007. Instruments to promote renewable energy in the German heat market-Renewable Heat Sources Act. Renew. Energ. 32:1127-1135.

Odling-Smee, L. 2007. Biofuels bandwagon hits a rut. Nature 446:483.

Okereke, C. \& Dooley, K. 2010. Principles of justice in proposals and policy approaches to avoided deforestation: Towards a post-Kyoto climate agreement. Global Environ. Change 20:82-95.

Om Tapanes, N.C., Gomes Aranda, D.A., de Mesquita Carneiro, J.W. \& Ceva Antunes, O.A. 2008. Transesterification of Jatropha curcas oil glycerides: Theoretical and experimental studies of biodiesel reaction. Fuel 87:2286-2295.

Orellana, C. \& Neto, R.B. 2006. Brazil and Japan give fuel to ethanol market. Nat. Biotechnol. 24:232.

Parker, J. 2002. Turning manure into gold. EMBO rep. 3:1114-1116.

Parry, M., Palutikof, J., Hanson, C. \& Lowe, J. 2008. Squaring up to reality. Nature Reports Climate Change 2, 68-70. 
Peters, W. et al. 2007. An atmospheric perspective on North American carbon dioxide exchange: CarbonTracker. Proc. Natl. Acad. Sci. USA 104:18925-18930.

Pousa, G.P.A.G., Santos, A.L.F. \& Suarez, P.A.Z. 2007. History and policy of biodiesel in Brazil. Energ. Policy 35:5393-5398.

Proctor, M.R., Taylor, E.J., Nurizzo, D., Turkenburg, J.P., Lloyd, R.M., Vardakou, M., Davies, G.J. \& Gilbert, H.J. 2005. Tailored catalysts for plant cell-wall degradation: Redesigning the exo/endo preference of Cellvibrio japonicus arabinanase 43A. Proc. Natl. Acad. Sci. USA 102:2697-2702.

Pryor, S.C. \& Barthelmie, R.J. 2010. Climate change impacts on wind energy: A review. Renew. Sustain. Energ. Rev. 14:430-437.

Pulz, O. \& Gross, W. 2004. Valuable products from biotechnology of microalgae. Appl. Microbiol. Biot. 65:635-48.

Rafaj, P. \& Kypreos, S. 2007. Internalisation of external cost in the power generation sector: Analysis with global multi-regional MARKAL model. Energ. Policy 35:828-843.

Ragauskas, A.J. et al. 2006. The path forward for biofuels and biomaterials. Science 311:484489.

Raghu, S., Anderson, R.C., Daehler, C.C., Davis, A.S., Wiedenmann, R.N., Simberloff, D. \& Mack, R.N. 2006. Adding biofuels to the invasive species fire? Science 313:1742.

Ramadhas, A.S., Jayaraj, S. \& Muraleedharan, C. 2005. Biodiesel production from high FFA rubber seed oil. Fuel 84:335-340.

Ratledge, C. 2002. Regulation of lipid accumulation in oleaginous micro-organisms. Biochem. Soc. Trans. 30:1047-1050.

Reay, D. 2007. Spring-time for sinks. Nature 446:727-728.

Ridgwell, A.T. \& Zeebe, R.E. 2005. The role of the global carbonate cycle in the regulation and evolution of the Earth system. Earth Planet. Sci. Lett. 234:299-315.

Romm, J. 2006. The car and fuel of the future. Energ. Policy 34:2609-2614.

Ross, D.K. 2006. Hydrogen storage: The major technological barrier to the development of hydrogen fuel cell cars. Vacuum 80:1084-1089.

Rothengatter, W. 2010. Climate change and the contribution of transport: Basic facts and the role of aviation. Transportation Research Part D 15:5-13.

Rout, U.K., Akimoto, K., Sano, F., Oda, J., Homma, T. \& Tomoda, T. 2008. Impact assessment of the increase in fossil fuel prices on the global energy system, with and without $\mathrm{CO}_{2}$ concentration stabilization. Energ. Policy 36:3477-3484.

Sánchez Mirón, A. Ceron Garcia, M.C., Contreras Gomez, A., Garcia Camacho, F., Molina Grima, E. \& Chisti, Y. 2003. Shear stress tolerance and biochemical characterization of Phaeodactylum tricornutum in quasi steady-state continuous culture in outdoor photobioreactors. Biochem. Eng. J. 16:287-297.

Sanderson, K. 2006. A field in ferment. Nature 444:673-676.

Scarlat, N. \& Dallemand, J.-F. 2010. Recent developments of biofuels/bioenergy sustainability certification: A global overview. Energ. Policy, doi:10.1016/ j.enpol.2010.12.039

Scharlemann, J.P.W. \& Laurance, W.F. 2008. How green are biofuels? Science 319:43-44.

Schiermeier, Q. 2008. Europe spells out action plan for emissions targets. Nature 451:504-505.

Schiermeier, Q., Tollefson, J., Scully, T., Witze, A. \& Morton, O. 2008. Electricity without carbon. Nature 454:816-823. 
Schmer, M.R., Vogel, K.P., Mitchell, R.B. \& Perrin, R.K. 2008. Net energy of cellulosic ethanol from switchgrass. Proc. Natl. Acad. Sci. USA 105:464-469.

Schultz, M.G., Diehl, T., Brasseur, G.P. \& Zittel, W. 2003. Air pollution and climate-forcing impacts of a global hydrogen economy. Science 302:624-627.

Searchinger, T. et al. 2008. Use of U.S. croplands for biofuels increases greenhouse gases through emissions from land-use change. Science 319 :1238-1240.

Sedjo, R.A. \& Marland, G. 2003. Inter-trading permanent emissions credits and rented temporary carbon emissions offsets: some issues and alternatives. Climate Policy 3:435-444.

Seibert, M., Forestier, M., Zhang, L. \& Ghirardi, M. 2001. Development of an efficient algal $\mathrm{H}_{2}$-production system. Proceedings of the 2001 DOE Hydrogen Program Review NREL/CP-570-30535, Accessed February 2, 2010. http://www1.eere.energy.gov/hydrogenandfuelcells/pdfs/30535c.pdf.

Shinnar, R. \& Citro, F. 2006. A road map to U.S. decarbonization. Science 313:1243-1244.

Simões, A.F., Kligerman, D.C., La Rovere, E.L., Maroun, M.R., Barata, M. \& Obermaie, M. 2010. Enhancing adaptive capacity to climate change: The case of smallholder farmers in the Brazilian semi-arid region. Environmental Science \& Policy 13:801-808.

Singh, J. \& Gu, S. 2010. Commercialization potential of microalgae for biofuels production. Renew. Sustain. Energ. Rev. 14:2596-2610.

Snyder, C.S., Bruulsema, T.W., Jensen, T.L. \& Fixen, P.E. 2009 Review of greenhouse gas emissions from crop production systems and fertilizer management effects. Agric. Ecosyst. Environ. 133:247-266.

Solomon, B.D. \& Banerjee, A. 2006. A global survey of hydrogen energy research, development and policy. Energ. Policy 34:781-792.

Song, C. 2006. Global challenges and strategies for control, conversion and utilization of $\mathrm{CO}_{2}$ for sustainable development involving energy, catalysis, adsorption and chemical processing. Catalysis Today 115:2-32.

Song, C.S. \& Pan, W. 2004. Tri-reforming of methane: a novel concept for catalytic production of industrially useful synthesis gas with desired $\mathrm{H} / \mathrm{CO}$ ratios. Catalysis Today 98:463-484.

Song, D., Fu, J. \& Shi, D. 2008. Exploitation of oil-bearing microalgae for biodiesel. Chinese Journal of Biotechnology 24:341-348.

Soong, R.K., Bachand, G.D., Neves, H.P., Olkhovets, A.G., Craighead, H.G. \& Montemagno, C.D. 2000. Powering an inorganic nanodevice with a biomolecular motor. Science 290:1555-1558.

Sorensen, B. 2007. Assessing current vehicle performance and simulating the performance of hydrogen and hybrid cars. Int. J. Hydrogen Energ. 32:1597-1604.

Spolaore, P., Joannis-Cassan, C., Duran, E., \& Isambert, A. (2006). Commercial applications of microalgae. J. Biosci. Bioeng. 101:87-96.

Steinberg, M. 2006. Conversion of fossil and biomass fuels to electric power and transportation fuels by high efficiency integrated plasma fuel cell (IPFC) energy cycle. Int. J. Hydrogen Energ. 31:405-411.

Stern, N. 2006. Review on the economics of climate change. Accessed February 2, 2010. http://www.hmtreasury.gov.uk/independent_reviews/stern_review_economics_climate_change/ stern_review_report.cfm. 
Sticklen, M.B. 2008. Plant genetic engineering for biofuel production: towards affordable cellulosic ethanol. Nature Rev. Genet. 9:433-443.

Stone, R. 2007. Can palm oil plantations come clean? Science 317:1491.

Styles, D. \& Jones, M.B. 2008. Life-cycle environmental and economic impacts of energycrop fuel-chains: an integrated assessment of potential GHG avoidance in Ireland. Environmental Science and Policy 11:294-306.

Subhadra, BG. 2010 Sustainability of algal biofuel production using integrated renewable energy park (IREP) and algal biorefinery approach. Energ. Policy 38:5892-5901.

Subramanian, K,A., Singal, S.K., Saxena, M. \& Singhal, S. 2005. Utilization of liquid biofuels in automotive Diesel engines: an Indian perspective. Biomass Bioenergy 29:65-72.

Sun, F. \& Chen, H. 2008. Enhanced enzymatic hydrolysis of wheat straw by aqueous glycerol pretreatment. Bioresource Technol. 99:6156-6161.

Szulczyk, K.R., McCarl, B.A. \& Cornforth, G. 2010. Market penetration of ethanol. Renew. Sustain. Energ. Rev. 14:394-403.

Takeshita, T. \& Yamaji, K. 2008. Important roles of Fischer-Tropsch synfuels in the global energy future. Energ. Policy 36:2773-2784.

Tan, K.T., Lee, K.T. \& Mohamed, A.R. 2008. Role of energy policy in renewable energy accomplishment: The case of second-generation bioethanol. Energ. Policy 36:33603365.

Theis, M., Skrifvars, B.-J., Zevenhoven, M., Hupa, M. \& Tran, H. 2006. Fouling tendency of ash resulting from burning mixtures of biofuels. Part 2: Deposit chemistry. Fuel 85:1992-2001.

Thomas, C.D. 2007. A sixth mass extinction? Nature 450:349.

Tijmensen, M.J.A., Faaij, A.P.C., Hamelinck, C.N. \& Van Hardeveld, M.R.M. 2002. Exploration of the possibilities for production of Fischer Tropsch liquids and power via biomass gasification. Biomass Bioenergy 23:129-152.

Tilman, D., Hill, J. \& Lehman, C. 2007. Response to comment on "carbon-negative biofuels from low-input high-diversity grassland biomass". Science 316:1567c.

Tollefson, J. 2008. Stoking the fire. Nature 454:388-392.

Tomkiewicz, M. 2006. Global warming: science, money and self-preservation. Comptes rendus Chimie $9: 172-179$.

Trabesinger, A. 2007. Power games. Nature 447:900-903.

UNFCCC 2002. Report of the Conference of the Parties on its Seventh Session, Marrakesh, 29 October to 10 November 2001, Document FCCC/CP/2001/13/add.1

Urry, J. 2008. Governance, flows, and the end of the car system? Global Environ. Change 18:343-349.

Velu, S., Suzuki, K., Vijayaraj, M., Barman, S. \& Gopinath, C. 2005. In situ XPS investigations of Cu1_xNixZnAl-mixed metal oxide catalysts used in the oxidative steam reforming of bio-ethanol. Applied Catalysis B: Environmental 55:287-299.

Venter, O., Meijaard, E. \& Wilson, K. 2008. Strategies and alliances needed to protect forest from palm-oil industry. Nature 451:16.

Venturi, P. \& Venturi, G. 2003. Analysis of energy comparison for crops in European agricultural systems. Biomass Bioenergy 25:235-255.

Vertès, A.A., Inui, M. \& Yukawa, H. 2006. Implementing biofuels on a global scale. Nat. Biotechnol. 24:761-764. 
Vogt, K.A. et al. 2008. Bio-methanol: How energy choices in the western United States can help mitigate global climate change. Renew. Energ. 34:233-241.

Vunjak-Novakovic, D., Kim, Y., Wu, X., Berzin, I. \& Merchuk, J.C. 2005. Air-lift bioreactors for algal growth on flue gas: mathematical modeling and pilot-plant studies. Ind. Eng. Chem. Res. 44:6154-6163.

Wall, D. 2004. Rain or shine - a phototroph that delivers. Nat. Biotechnol. 22:40-41.

Walter, A., Dolzan, P., Quilodrán, O., de Oliveira, J.G., da Silva, C., Piacente, F. \& Segerstedt, A. 2010. Sustainability assessment of bio-ethanol production in Brazil considering land use change, GHG emissions and socio-economic aspects. Energ. Policy, doi:10.1016/j.enpol.2010.07.043

Werner, F., Taverna, R., Hofer, P., Thürig, E. \& Kaufmann, E. 2010. National and global greenhouse gas dynamics of different forest management and wood use scenarios: a model-based assessment. Environmental Science E policy 13:72 - 85.

Wesseler, J. 2007. Opportunities ('costs) matter: A comment on Pimentel and Patzek "Ethanol production using corn, switchgrass, and wood; biodiesel production using soybean and sunflower". Energ. Policy 35:1414-1416.

Willner, I. 2002. Biomaterials for sensors, fuel cells, and circuitry. Science 298:2407-2408.

Wolfrum, E.J. \& Watt, A.S. 2001. Bioreactor design studies for a novel hydrogen-producing bacterium. Proceedings of the 2001 DOE Hydrogen Program Review, NREL/CP570-30535.

Woodcock, J., Banister, D., Edwards, P., Prentice, A.M. \& Roberts, I. 2007. Energy and health 3, energy and transport. Lancet 370:1078-1088.

Xue, F., Miao, J., Zhang, X., Luo, H. \& Tan, T. 2008. Studies on lipid production by Rhodotorula glutinis fermentation using monosodium glutamate wastewater as culture medium. Bioresource Technol. 99:5923-5927.

Yang, Z. \& Sirianni, P. 2010. Balancing contemporary fairness and historical justice: A 'quasiequitable' proposal for GHG mitigations. Energ. Econ. 32:1121-1130.

Yasuda, R., Noji, H., Yoshida, M., Kinosita, K. \& Itoh, H. 2001. Resolution of distinct rotational substeps by submillisecond kinetic analysis of F1-ATPase. Nature 410:898-904.

Yue, T.-X., Fan, Z.-M., Chen, C.-F., Sun, X.-F.\& Li, B.-L. 2010. Surface modeling of global terrestrial ecosystems under three climate change scenarios. Ecol. Model., doi:10.1016/j.ecolmodel.2010.11.026

Zhang, Y., Dubé, M.A., McLean, D.D. \& Kates, M. 2003. Biodiesel production from waste cooking oil: Process design and technological assessment. Bioresource Technol. 89:116.

Zhou, X., Xiao, B., Ochieng, R.M. \& Yang, J. 2008. Utilization of carbon-negative biofuels from low-input high-diversity grassland biomass for energy in China. Renew. Sustain. Energ. Rev. 13:479-485. 


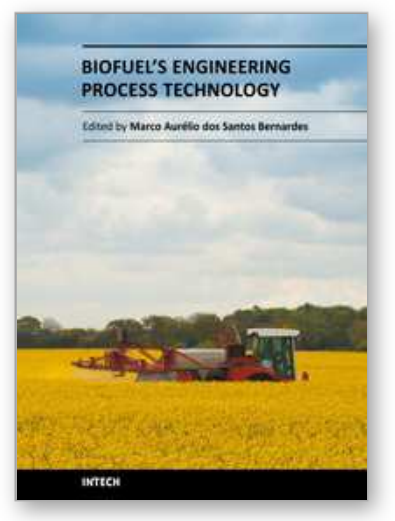

\author{
Biofuel's Engineering Process Technology \\ Edited by Dr. Marco Aurelio Dos Santos Bernardes
}

ISBN 978-953-307-480-1

Hard cover, 742 pages

Publisher InTech

Published online 01, August, 2011

Published in print edition August, 2011

This book aspires to be a comprehensive summary of current biofuels issues and thereby contribute to the understanding of this important topic. Readers will find themes including biofuels development efforts, their implications for the food industry, current and future biofuels crops, the successful Brazilian ethanol program, insights of the first, second, third and fourth biofuel generations, advanced biofuel production techniques, related waste treatment, emissions and environmental impacts, water consumption, produced allergens and toxins. Additionally, the biofuel policy discussion is expected to be continuing in the foreseeable future and the reading of the biofuels features dealt with in this book, are recommended for anyone interested in understanding this diverse and developing theme.

\title{
How to reference
}

In order to correctly reference this scholarly work, feel free to copy and paste the following:

Nicolas Carels (2011). The Challenge of Bioenergies: An Overview, Biofuel's Engineering Process Technology, Dr. Marco Aurelio Dos Santos Bernardes (Ed.), ISBN: 978-953-307-480-1, InTech, Available from: http://www.intechopen.com/books/biofuel-s-engineering-process-technology/the-challenge-of-bioenergies-anoverview

\section{INTECH}

open science | open minds

\section{InTech Europe}

University Campus STeP Ri Slavka Krautzeka 83/A 51000 Rijeka, Croatia Phone: +385 (51) 770447 Fax: +385 (51) 686166 www.intechopen.com

\author{
InTech China \\ Unit 405, Office Block, Hotel Equatorial Shanghai \\ No.65, Yan An Road (West), Shanghai, 200040, China \\ 中国上海市延安西路65号上海国际贵都大饭店办公楼405单元 \\ Phone: +86-21-62489820 \\ Fax: $+86-21-62489821$
}


(C) 2011 The Author(s). Licensee IntechOpen. This chapter is distributed under the terms of the Creative Commons Attribution-NonCommercialShareAlike-3.0 License, which permits use, distribution and reproduction for non-commercial purposes, provided the original is properly cited and derivative works building on this content are distributed under the same license. 